Article

\title{
Standardization Framework for Sustainability from Circular Economy 4.0
}

\author{
María Jesús Ávila-Gutiérrez * (D), Alejandro Martín-Gómez, Francisco Aguayo-González \\ and Antonio Córdoba-Roldán \\ Design Engineering Dept, University of Seville, Escuela Politécnica Superior, Virgen de África 7, \\ 41011 Seville, Spain; ammartin@us.es (A.M.-G.); faguayo@us.es (F.A.-G.); acordoba1@us.es (A.C.-R.) \\ * Correspondence: mavila@us.es
}

Received: 8 October 2019; Accepted: 15 November 2019; Published: 18 November 2019

check for updates

\begin{abstract}
The circular economy (CE) is widely known as a way to implement and achieve sustainability, mainly due to its contribution towards the separation of biological and technical nutrients under cyclic industrial metabolism. The incorporation of the principles of the $C E$ in the links of the value chain of the various sectors of the economy strives to ensure circularity, safety, and efficiency. The framework proposed is aligned with the goals of the 2030 Agenda for Sustainable Development regarding the orientation towards the mitigation and regeneration of the metabolic rift by considering a double perspective. Firstly, it strives to conceptualize the $\mathrm{CE}$ as a paradigm of sustainability. Its principles are established, and its techniques and tools are organized into two frameworks oriented towards causes (cradle to cradle) and effects (life cycle assessment), and these are structured under the three pillars of sustainability, for their projection within the proposed framework. Secondly, a framework is established to facilitate the implementation of the CE with the use of standards, which constitute the requirements, tools, and indicators to control each life cycle phase, and of key enabling technologies (KETs) that add circular value 4.0 to the socio-ecological transition.
\end{abstract}

Keywords: standardization framework; circular economy; engineering projects; metabolic rift; key enabling technologies; digital transformation

\section{Introduction}

The current model of appropriation of natural resources under a linear economy has triggered serious environmental problems, which puts the continuity of the biosphere and its resource provider ecosystems at risk [1]. However, interest in carrying out personal and collective changes in the face of this challenge remain limited and requires a socio-ecological transition model that articulates the advantages of frameworks, techniques, and tools for eco-efficiency and eco-effectiveness [2]. Achievement of the sustainable development goals of the 2030 Agenda requires a new paradigm for sustainability that integrates these techniques, tools, and frameworks under new principles, such as circularity, eco-effectiveness, and harmlessness [3].

The majority of current arrangements for the preservation of the environment involve palliative actions; however, these actions should be aimed at decoupling economic growth and the loss of environmental value [4]. These can be classified as actions oriented either towards effects or towards causes on economic, social, and environmental aspects. Among the actions oriented towards effects, the most representative techniques include life cycle assessment (LCA) [5,6], remanufacturing [7], recycling [8], etc. About second actions are those which are oriented to causes, such as, cradle to cradle (C2C) [9] or biodesign [10].

From a more aggregate perspective, productive activity has been oriented towards two approaches that correspond to: The so-called linear economy, or scarcity, with linear flows from the cradle to 
the grave (landfill); and CE, or economy of abundance, which is characterized by two nutrient flows (biological and technical) cycled over the natursphere and technosphere. The CE includes the objective of promoting value creation by reducing resources, costs, and impacts, together with other alternatives, such as collaborative economics [11]. In this respect, the CE [12] appears to constitute a paradigm for sustainability as a generator of a regenerative metabolism of the metabolic rift determined by the built environment [13]. However, although the CE is denominated as a paradigm in numerous investigations [14], research has yet to be presented that characterizes the $\mathrm{CE}$ according to the aspects that a paradigm must possess $[15,16]$.

Based on the above, and with respect to the methodological aspects of the CE paradigm, a set of frameworks, techniques, and tools have been developed aimed at creating value, such as $\mathrm{C} 2 \mathrm{C}$, bioinspired design, and eco-effectiveness. Likewise, other tools, such as LCA, impact-oriented design, and eco-efficiency, assess the damage or loss of environmental value. These techniques have different objectives and can complement each other. LCA is an evaluation method that guides the action from eco-efficiency under the knowledge of the effects (impacts and damages), while C2C is a different approach that points towards sustainable design from the knowledge of the causes and ecoeffectiveness [17]. From this point of view, $\mathrm{C} 2 \mathrm{C}$ as a generator method can inspire designers to various design solutions, while LCA can be used as an analytical tool for the assessment of the sustainability of these design solutions, of the performance of eco-innovations, and also as design-process tracking [3,5].

The aforementioned scenario offers the opportunity to provide the scientific and technical community with a unified paradigm that configures the path towards developing technical systems and services (built environment) in a sustainable manner in their life cycle under a multilevel and multiscale approach (geographical dimension). In this respect, a variety of proposals have been developed [18-20] of which CE [21] is considered as a paradigm to structure the body of knowledge (Noosphere) of the triple bottom line (TBL) that enables the socio-ecological transition.

A consistent step towards implementing the CE paradigm and its principles in organizations is that of standardization. Therefore, from among the various proposals that have been put forward on the normalization of CE [22,23], these approaches of normalization are shown to lack the full potential of the consideration of $\mathrm{CE}$ as a paradigm of sustainability and its incorporation into the concept of excellence of sustainability. This latter characteristic is considered to be the most evolved concept of quality towards business excellence under the European foundation quality management (EFQM) and Malcolm Baldrige models [24].

Standards provide a source of information and serve as a channel for the transfer of technology for the propagation and distribution of knowledge [25]. Standardization is identified in Horizon 2020 as one of the innovation-support measures since it bridges the gap between research and the market and facilitates the fast and easy transfer of research results to the European and international market [26].

Therefore, this paper addresses the following research questions: (i) Is it possible to formulate the $\mathrm{CE}$ as a paradigm for sustainability according to the basic aspects that a paradigm must possess? (ii) How should the emerging knowledge of lessons learned and best available techniques (BAT) of sustainable industrial practices be transferred to technical standards for the circular economy, in order to ensure the greatest scope of sustainability in industrial and service operations? (iii) How can the potential of digital transformation of Industry 4.0 and a framework for standardization committees that transfer knowledge and edge experience to technical standards be articulated synergistically?

The main contributions of this research include: The formalization of $\mathrm{CE}$ as a paradigm for sustainability; and the establishment of a multilevel and multiscale standardization framework to transfer the emerging knowledge of scientific research on sustainability to technical standards for the $\mathrm{CE}$ in order to ensure the greatest scope both of sustainability in industrial and service operations, from the informational perspective, and the opportunities of digital transformation.

In this work, a review of various aspects of the $\mathrm{CE}$ and digital transformation is carried out in order to structure work frameworks under the principles of the $\mathrm{CE}$ and the pillars of sustainability, and subsequently to formulate a proposal for the development of standardization of the $\mathrm{CE}$ as a 
paradigm for sustainability under the potential offered by digital transformation. This proposal can be employed by the various committees of standardization bodies for the development of families of $\mathrm{CE}$ norms integrated from an epistemological foundation. It is articulated on several levels (multilevel) and at several scales and is oriented towards the mitigation of the metabolic rift under the consideration of the potential of digitalization, connectivity, and intelligence that are inherent in the processes of digital transformation. Its degree of generality is such that it can be specified according to the characteristics of the various sectors, countries, and regions.

In this work, a review is carried out in Section 2 from different aspects of CE and digital transformation, in order to structure a unified framework under the principles of CE and the pillars of sustainability. Subsequently, in Section 3, a proposal is formulated for the development of the standardization of the CE as a paradigm for sustainability under the potential offered by digital transformation. Section 4 presents an illustration with the study of product standards for their projection to standardization in accordance with CE principles and digitalization. Finally, Section 5 presents the conclusions regarding the questions and research objectives raised.

\section{Literature Review}

In this work, a status quo review is carried out based on the types of revision proposed by Mayer [27], who defines this type of review as a description of the state-of-the-art research on the particular topic or field of study. Based on the types of bibliographic research proposed by Squires, a descriptive review will be made. Squires [28] defines this type of review as an up-to-date proposal on useful concepts in constantly evolving areas. This type of review is descriptive and shows the state of knowledge regarding the topics investigated [29]. These two types of review complement each other since they control the revision of a topic or concept from different descriptive points of view.

The background identifies the theories and prior research that provide information for a solid conceptual framework. The review of the literature creates an organizing component for the manuscript as shown in Figure 1.

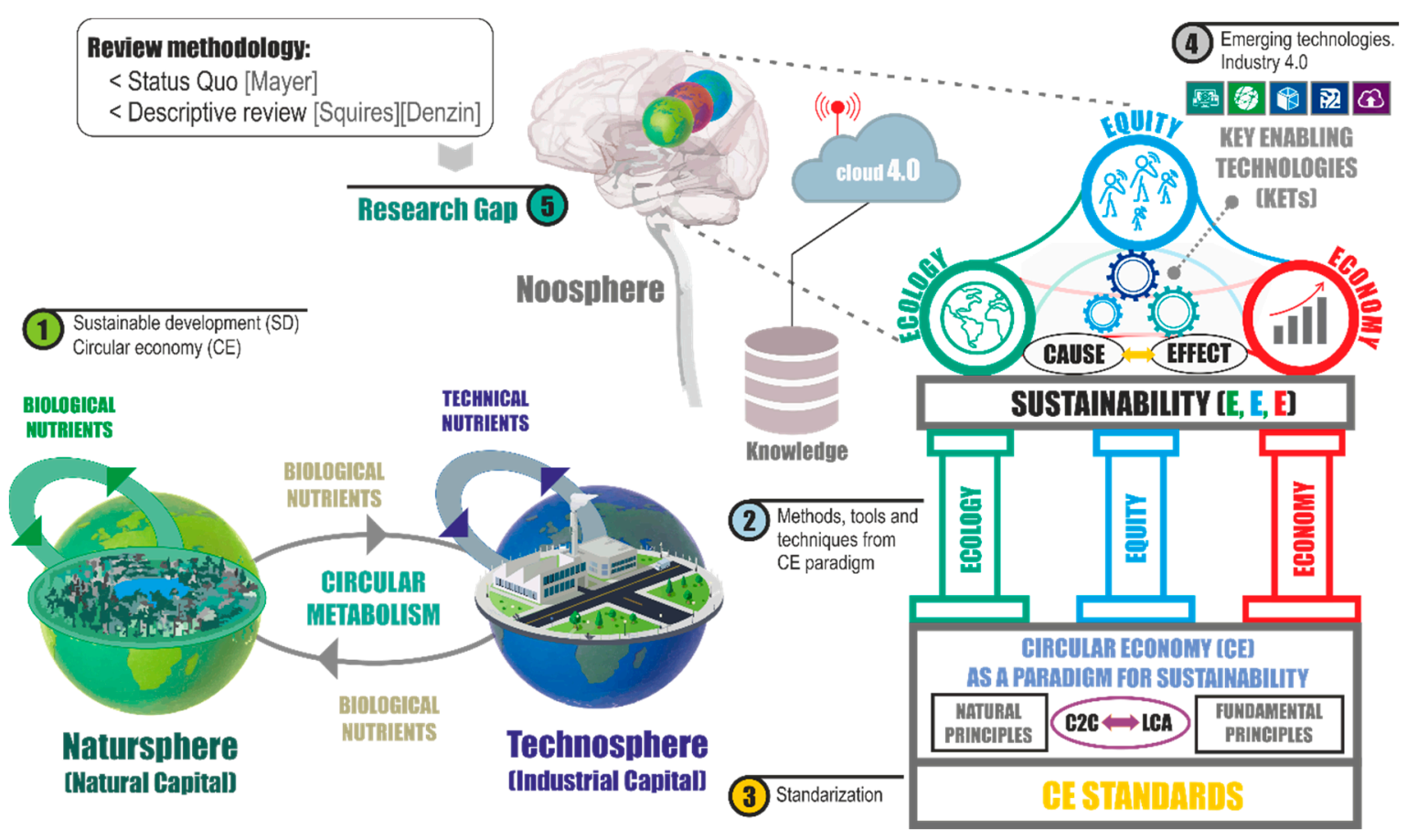

Figure 1. Sustainable development and circular economy as a paradigm.

Focusing on four principal points, it first defines concepts such as sustainable development, the circular economy, and metabolism. Derived from the metabolism in the technical and natural 
cycles, several characteristics arise that are featured in each of the three pillars of sustainability (3E): Ecology (E), equity (E), and economy (E). Second, based on these three pillars, there are methods, tools, and techniques of application in each pillar that must be studied for their integration under the principles of the CE. Third, the information resulting from the investigation must be collected in a standard or technical document, and fourth, all information must be managed and monitored with the help of emerging technologies provided by Industry 4.0.

The review of the literature is organized based on the consideration of the $\mathrm{CE}$ as a paradigm for sustainability, and includes: (1) The establishment of the principles of the CE; (2) a brief analysis of the methodologies, techniques, and tools under the TBL; (3) the study of standards for the CE; and (4) the study of emerging technologies under Industry 4.0.

\subsection{Sustainable Development and Circular Economy}

The analysis of a large number of investigations has been carried out, regarding the clarification of the connection between sustainable development (SD) and the $\mathrm{CE}$, and focusing on their principles and models, and has also included the implementation at the different levels of concretion (macro, meso, and micro) [30]. It follows that, hitherto, the CE has placed environmental sustainability in the foreground in order to recognize the need for a favorable economic context (the circular model of appropriation of natural resources) but has, on many occasions, left the social objective trailing in third place.

The CE concept, as a paradigmatic framework for sustainability, is based on the following three fundamental principles [13,31]: (1) Preserve and improve the natural capital; (2) optimize the resource performance; and (3) enhance the effectiveness. Its natural principles are [32,33]: Design without waste; develop the resilience from the diversity; use resources and renewable energies; employ system thinking; and make use of cascade effect thinking.

The central point of these two concepts (SD and CE) should be a framework oriented towards the action of economic, social, and environmental objectives [34], which take into account the premises of sustainable development in conjunction with the techniques and tools of the CE [3]. These techniques and tools aim to close the gap between the synergic articulation of the three fundamental pillars of sustainability which are oriented towards the regeneration of the metabolic rift. The SD and CE concepts overlap and seek solutions using different approaches, as can be seen in Figure 1. According to Ghisellini [35], there are implementations of the CE classified into macro, meso, and micro levels, but they lack an integrative framework that enables operation on all levels. Among the most recent research lies the analysis of the concept of the $\mathrm{CE}$ that now prevails in the debate on policies and business development regarding the sustainable development of industrial production.

Policy development agencies and business associations consider that the $\mathrm{CE}$ is a crucial mechanism for the promotion of sustainable production. It is identified as bringing a potential paradigmatic change that, consequently, will lead to industrial transformations. The expectation is that the adoption of the CE will fundamentally transform economic activities, thereby limiting dependence on non-renewable and intensive carbon flows, and leaning towards a more sustainable production and consumption. An interesting aspect is that shown in Lieder and Rashid [36], where the top-down and bottom-up approach of the CE is established. These two concepts should be treated neither separately nor as competitors, but instead as being complementary and, in certain cases, as overlapping at a conceptual level, since they may both contemplate sustainable development from the TBL. It is especially necessary to consider the $\mathrm{CE}$ as a paradigm of the economy of sustainability for its integration into the development of policies that determine a circular industrial metabolism, thereby contributing the principles to the three pillars of sustainability.

\subsection{Circular Economy Methods, Techniques, and Tools from the TBL}

One major issue for research on the CE paradigm involves the identification of whether there are methodologies, techniques, tools, and indicators currently being used successfully to assess the 
effectiveness of CE-based strategies in the three areas of value: (a) Environmental; (b) economic; and (c) social [37]. These are presented for each pillar of sustainability.

(a) Environmental value. Among the methodologies and techniques based on indices in relation to the environmental value in the $\mathrm{CE}$, three points of view are identified: Circularity of materials and water, energy flow, and toxicity.

The following techniques and tools can be found regarding circularity of materials and water: (1) Material flow analysis, a technique widely used in the evaluation of the metabolism of the regions, and the application of the $\mathrm{CE}$ to map global flows of materials, explore possible measures to promote $\mathrm{CE}$, and evaluate the impact of using approaches to achieve CE [38]; (2) LCA, as a multi-indicator technique that facilitates in the identification of the possible impacts associated with products throughout their life cycle. Regarding its fit in the CE, LCA can facilitate the verification of impacts in circular manufacturing systems, validate the assumptions of departure, and obtain feedback for the improvement process. It can also help define objectives and indicators for the measurement and promotion of circularity over time [39]; (3) material input per service unit [40], employed to measure impacts related to a specific flow of materials, which enables all the material inputs required for the product or process unit to be estimated throughout all phases of the life cycle; (4) ecological rucksack [41], which allows the intensity of material consumption to be measured; (5) water circularity (water footprint); (6) longevity indicator used in decision-making and evaluation of CE; (7) Input-output analysis [42], employed to calculate the industrial metabolism of a region, to measure the technical efficiency of industrial networks, and to model dynamic input-output analysis for waste generation and recycling in an area linked to the LCA in the form of the analysis of material flow and life cycle cost; (8) trophic chain [43] classification of species to establish the flows and balances of matter and energy in the chain; (9) industrial symbiosis [44], where a network of exchanges between industries is established; (10) analysis of ecological networks based on the theory of networks [45], which enables the quantification of the structure of metabolic pathways of the system, the characteristics of metabolic flows, and the interspecific relationships between the individuals that make up the industrial ecosystem; and (11) biogeochemical cycles [46], for the identification and adaption of the flows and rhythms of extraction and deposition of materials and energy, by the social system, to the cycles and rhythms of the planet.

The energy flow view features: (1) Embedded energy analysis, an index of all direct and indirect energy flows necessary to produce a product or service, which together with the analysis of ecological networks enables the energy metabolism from a region to be established [47]; (2) exergy analysis [48], as a thermodynamic measure of energy quality; (3) emergy analysis [49], to evaluate the dynamics of an ecosystem; (4) analysis of social exergy and (5) the Sankey diagram, for the identification of system boundaries and units of flow and stocks.

The toxicity view includes: (1) Substance flow analysis [50], which is especially useful for evaluating the flows and impacts of chemical substances and relevant information on the extent of contamination; (2) LCA toxicity in humans and ecotoxicity; (3) substance analysis from C2C; and (4) bioinspired/biomimetic design [51].

(b) Economic value. The environment, from the perspective of the economy, fulfills four basic functions for well-being: Comfort values; a resource base for the economy; a sink for residual flows; and a life-support system [52]. The CE, based on the principle of material balance, enables economic values and not just physical flows to be identified, in order to guide management. The following are methods that allow the economic sustainability of products, processes, and systems to be evaluated: (1) Life cycle cost analysis [53]; (2) economic network analysis; (3) cost-benefit analysis; (4) eco-costs as a measure to express the amount of environmental load of a product based on the prevention of that load; (5) eco-cost/value relationship; and (6) eco-efficient value creation focusing on the two-dimensional analysis and design of the ecological load and the market value of a system. From the CE, this method is employed to analyse products and services in order to design innovative products and circular business strategies. 
(c) Social value. The social aspect of sustainability is perhaps the most commonly forgotten of the three aspects. In many cases, a clear definition of impacts and causes is lacking, and therefore it occupies a minor place in the evaluation of sustainability. The loss of social value caused in the metabolic rift can be reversed by studying the social value based on the contribution and arbitration that can take place on the concept of the CE. The following are identified: (1) Actor network theory; (2) socio-constructivism [54]; and (3) social life cycle assessment (S-LCA) as an evaluation of the social impacts of the social and socio-economic life cycle, whereby the social impacts are mainly on human capital, human well-being, cultural heritage, social economy, and social behaviour [55]; and (4) social network [56].

This section considers an overview of the literature regarding techniques and tools for sustainability. The objective is to establish a set of articulated tools not only from a variety of frameworks but also contextualized in the CE paradigm. This may constitute a highly useful instrument for sustainability.

\subsection{Circular Economy Standardization}

The movement towards the CE has been identified as a significant business opportunity [36]. Currently, $\mathrm{CE}$ regulations make it operable for organizations that need to complement national policies and laws. Among the most significant existing standards are those of Spain Circular 2030, ISO/TC 323, and BS 8001:2017, at the international level.

Spain Circular 2030 emerges as the first attempt to consolidate, at the regulatory level, the achievement of the sustainable development goals (SDGs) in a coherent manner [22]. This online tool, which shows all the UN SDGs, offers examples of more than 600 standards that support the SDGs, and aims to stimulate the progress of those organizations that wish to render the 2030 Agenda a reality. This strategy sets a national framework that enables the deployment of the necessary measures to promote the integration of the CE and sustainability in a competitive way in the 2030 international framework. This strategy contains an action plan 2018-2020 "Production and Design": Action 3 "Development of European eco-design standards and circular economy", which gives continuity to the current state of normalization of the CE [57].

The ISO/TC 323 standard was proposed by France and accepted by ISO in 2018, with 26 countries in favour of this new technical committee. The scope covers the standardization in the field of the CE, to develop the requirements, frameworks, guides, and support tools related to the implementation of CE projects. The proposed deliverables can be applied to any organization or group of organizations that wish to implement economic projects. Specifications of particular aspects of the $C E$ are already covered by existing codes, such as eco-design, and LCA in ISO/TC207 Environmental management and sustainable purchasing (ISO 20400:2017-Sustainable purchasing: Guidance).

Three major aspects will be discussed in future programs: (1) Standards management: Standards system management, implementation guidelines, and circular business models; (2) support tools: Including terminology, performance evaluation, flow of materials in the circular value chain, measures of the degree of circularity of products and services; and (3) review of guides: Industrial symbiosis, functional economy, frameworks for the $\mathrm{CE}$ for territories and local authorities, waste management, responsibilities of retailers, and recovery of materials for industrial sectors.

The BS 8001:2017 Framework was proposed by the United Kingdom for the implementation of CE principles in organizations. This describes what the $\mathrm{CE}$ is and how an organization can transition to greater circularity and sustainability. In order to support the framework, BS 8001 provides a guide on the specific problems surrounding the transition to a circular model, namely, measurements, liability and insurance, and logistical and material concerns [23].

In addition to the standards, Vanhamaky [17] reviews the current news of the CE together with the bioeconomy. The CE and the bioeconomy are partners in sustainability. Their political agendas have similar objectives and areas of intervention. A circular and bioeconomic approach can help preserve material value and functionality for longer. In response to this concept, a qualitative review is performed regarding Finland, Spain, Slovakia, Greece, Romania, and France and is framed in three 
levels: (1) Macro-level: European Union, nations, cities and regions; (2) meso-level: Local ecosystems and industrial networks; and (3) micro-level: Companies and consumers. The bio-based CE addresses the environmental and economic perspective, although the social perspective remains relegated to the background. All regulations, tools, and indicators must contain the vision of the three aspects of sustainability: Environmental, economic, and social.

\subsection{Emerging Technologies in Industry 4.0}

Together with the international strategies of ecological and energy transition, there are strategies of connected industry (or Industry 4.0) and of digital transformation [58]. These strategies are complementary to the $\mathrm{CE}$ and synergistic effects can be established between them. Digital transformation is determined by technological changes and the way in which people begin to interact with objects and with other people, as well as the relationships between products, their connections, and their control. Interconnectivity between devices and people will influence technological trends in the future [59]. Within the emerging technologies, two principal classifications can be found: Enabling technologies that help to process digital information such as cloud computing or big data; and those that include the Internet of Things (IoT) or cyber-physical systems, among others.

There is a wide variety of emerging technologies that allow the hybridization of the physical and digital world, which gives rise to the concept of a cyber-physical system as an object with a double existence (physical and real) [60] and another digital twin (digital and virtual) [61]. From among these, it is worth highlighting the sensors in products and processes [62], embedded systems [63], robotics and automation [63], additive manufacturing [64], artificial vision and intelligence [65], augmented and virtual reality [66], simulation and virtualization of production [65,67], connectivity of the company with the consumer [68], social networks [69,70], electronic commerce [71], cyber-security [72], advanced cloud computing [73], and digital twin and collaborative platforms [74]. Following an overview, we will proceed to establish a review and a study of the main technologies.

The hybridization of both strategies (CE and digital transformation) [75] allows a symbiosis between the applications, such as business product life management (PLM), for product and processes, and building information management (BIM) for buildings and facilities in a closed loop [76], connected LCA, and connected intelligent metabolism [77]. Hence, sustainability can be monitored and controlled in real time, through surrogate models obtained via big data techniques on digital twins [78].

As shown in Figure 2, synergies of the implementation of sustainability through the CE paradigm, together with the digital transformation, allow greater scope and efficiency of the frameworks, techniques and tools, together with multilevel and multiscale TBL integration (ISO 9001, 14001, 45001), in order to mitigate the metabolic rift. 


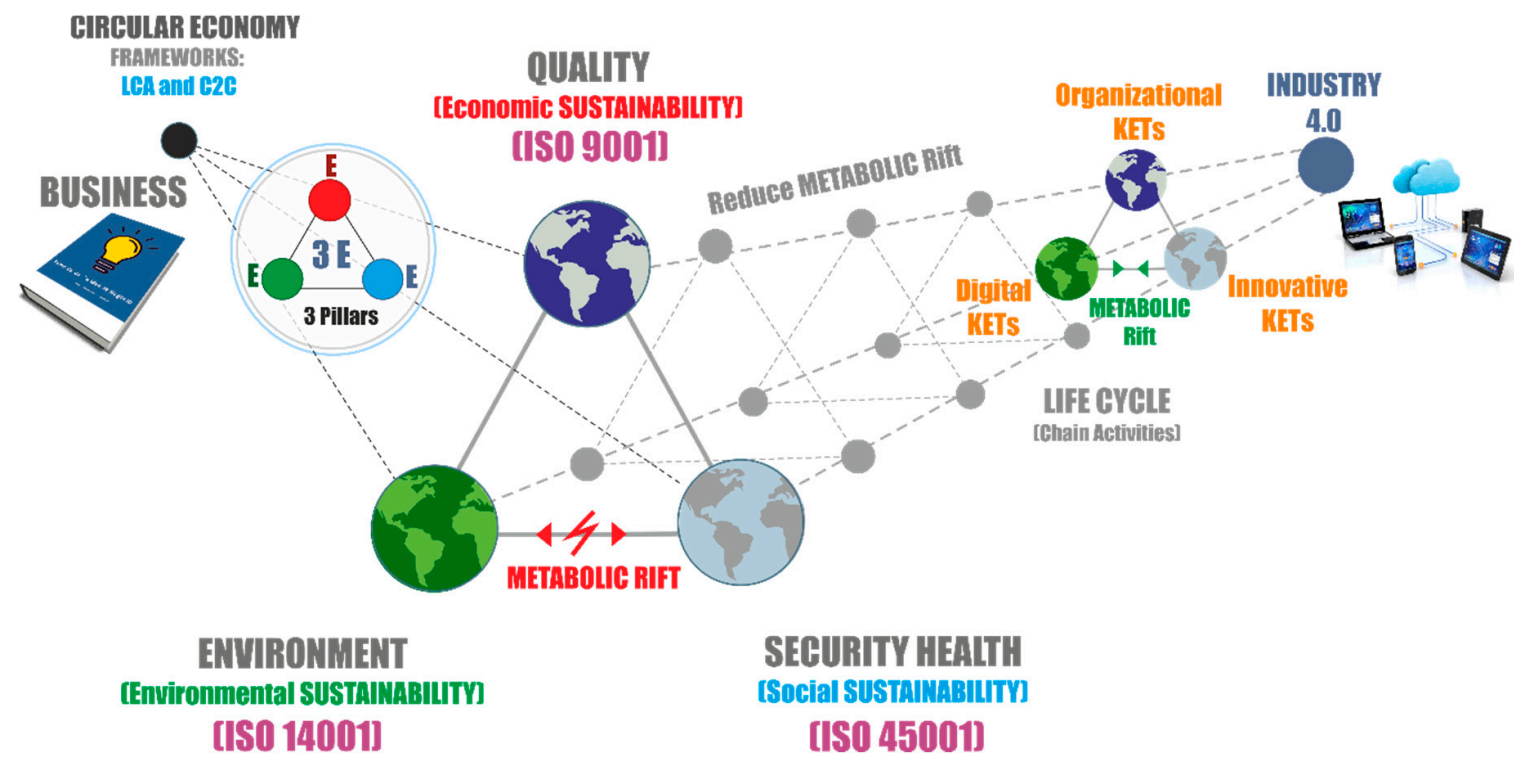

Figure 2. Circular economy 4.0.

This determines an increase in the scope of sustainability throughout the life cycle based on cyber-physical systems and collaborative economy strategies from the perspective of life cycle engineering at various levels of granularity and geographic scales.

\subsection{Research Gap}

The background presented herein provides an overview of the research, whereby various points have been identified that need to be systematically addressed.

There is great diversity in the research and knowledge regarding CE and sustainability. The CE constitutes a significant mechanism for the promotion of sustainability. Research into complex sustainability problems requires input from various domains of knowledge. It is evident that, due to the abundance of conceptualizations of the $\mathrm{CE}$ and various implementation strategies, it becomes a challenge for decision makers from industry to identify which initiative would bring the most benefits to them and their stakeholders. This abundance of research and concepts makes it necessary to characterize the circular economy from a unified point of view and an epistemological basis in order to establish a single umbrella that organizes families of CE standards. Derived from the study conducted in previous sections, no concretion of the $\mathrm{CE}$ as a paradigm of sustainability has been found and there is a gap between emerging knowledge of sustainability research and sustainability standards for operational excellence [79].

Standardization activities are recognized as one of the tools to incubate research results and accelerate their transfer to innovative marketable products and services. Sales [80] analyses the root causes for this gap and proposes a way forward. This author establishes that standardization should be supplemented by a methodology and its associated process through the systematic analysis of the standardization aspects and by facilitating the drawing up of their standardization strategy. Despite the existence of step-by-step methodologies, there is no multilevel and multiscale integrative framework that contains all the stakeholders in production sectors throughout their life cycle. It is necessary contemplate not only aspects of sustainability [79] but also tools and indicators (KPI) [81]. In order to identify standardization needs [82] and to integrate the use of tools in the circular economy, it is essential to search for standards that support circularity in the ecosystem in terms of the circular value chain to the product.

A standard generally refers to a common set of quality norms or criteria [83]. Many studies have examined standards. A growing body of studies include a wide range of perspectives, since many investigations have been conducted in a fragmentary way. Several initiatives in this field have been 
started or are in the process of design. The aim is to transfer results from research into knowledge that is useful to society, and to translate societal needs for knowledge into science questions and operational research $[80,84-86]$. For the transfer of the emerging knowledge to technical standards for the circular economy, the characterization of the different agents of the integrated ecosystem is required, whereby the norms, tools, and indicators are specified for each agent in each phase of their life cycle. Hitherto, standards have been found in a disaggregated manner which lacks specification of the concretion study level and of the phase of the life cycle in which they operate. It is necessary to provide an appropriate platform for standardization at each ecosystem level.

Digital technologies play a major role in the transition towards a more circular economy due to their ability to close the material loop regarding life cycle stages. Although their importance is not contested, the maturity level of digital technologies is disputed and the economic, environmental, and societal benefits are not contemplated. The principal gap identified in this study is that of the limited technological perspective, since the interplay between data collection, data integration, and data analysis is well understood [59]. An integrated framework is needed that offers a unique vision of technologies because current studies offer diverging views on the maturity of digital technologies and the life cycle stages. The potential of digital transformation can be articulated synergistically for standardization committees from a unified framework.

This paper contributes towards closing this gap in the literature. It integrates literature regarding sustainability and the $\mathrm{CE}$ and its projection to epistemological bases. An analysis of the appropriate methods, tools, and techniques is carried out from the sustainability perspective, and their incorporation into the integrated framework is examined. The creation and diffusion of technical standards with the recent literature are also studied in order to analyse the process of setting standards. Furthermore, this paper studies digital technologies for their implementation into the proposed framework.

\section{Conceptual Framework}

Nowadays, the CE is proposed as a paradigm for sustainability that determines the organizational behaviour of companies and institutions in a sustainable way. This paradigm is supported by a five-stream structure, as shown in Figure 3, the principal aspects are integrated in accordance with the following description of the aspects: Axiological (determination of environmental, social, and economic values); teleological (to obtain a triple income statement, that is, a TBL; ontological (in the fields of natursphere, technosphere, and metabolism); epistemological (to articulate the knowledge of nature, that is, is a model, measure, and mentor); and methodological (to apply the frameworks, techniques, and tools).

The $\mathrm{CE}$, as a paradigm, integrates various frameworks, such as those oriented towards either causes (C2C) or effects (LCA), and even features joint action between orientations towards both causes and effects (LCA and C2C) [87]. All this framework is articulated with the intentionality (teleological) of the TBL, and from economic, environmental, and social values (axiology), in order to consider an abstract representation of the elements involved in natursphere, technosphere, and their exchanges of matter and energy or circular metabolism.

The approach assumes nature as a model, measure, and mentor, and works from structured frameworks with techniques and tools oriented towards causes or effects. In this way, the CE is the bearer of the principles upon which the three pillars of sustainability (economy, equity, environmental) are established, so that the scientific and technical foundations of the frameworks, techniques, and tools can be built in order to achieve the socio-ecological transition. This justifies the structure of the paradigm of the CE with the five streams (axiological, teleological, ontological, epistemological, and methodological) as depicted in Figure 3, or the various national or international norms and standards as an operational way of refining or consolidating the methodologies, techniques, and tools that are being used successfully to evaluate the effectiveness of CE-based strategies. Likewise, their implementation is carried out in the three areas of value (environmental, social, and economic) [37], all with the potential offered by digital transformation, connectivity, and smartization. 


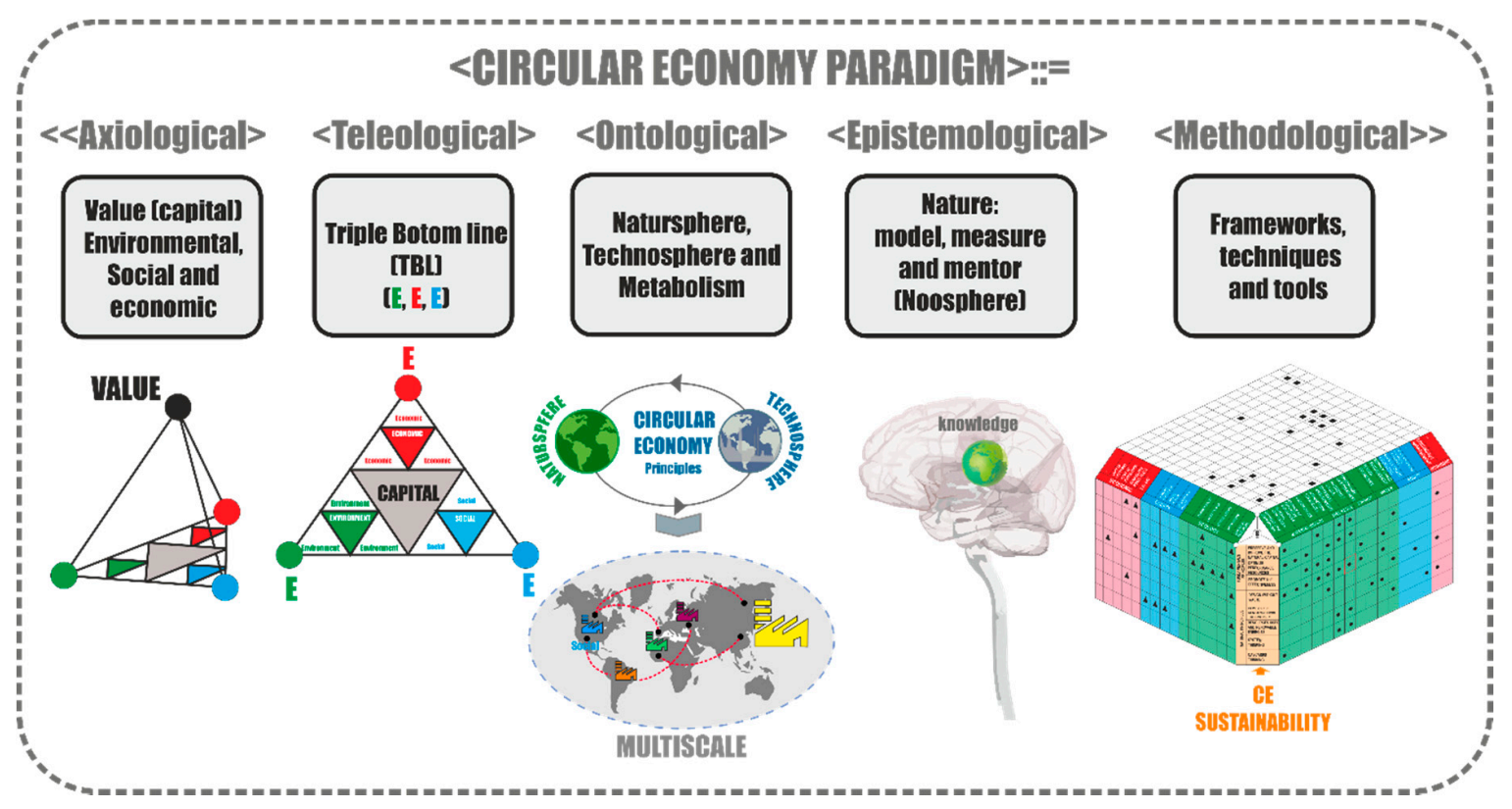

Figure 3. Circular economy as a paradigm for sustainability.

Based on the above, a framework for the establishment of the metabolism between productive and service systems for a model of appropriation of sustainable natural resources from the CE is presented in Figure 4. The objective is to articulate the elements of the CE paradigm (principles, pillars of sustainability, and frameworks) oriented towards the causes ( $\mathrm{C} 2 \mathrm{C}$ being the most representative) and towards the effects (in which LCA is the most representative), and the technological, digital, and organizational facilitators of the digital transformation of Industry 4.0 to determine a connected intelligent circular (social) industrial metabolism. The integration of the value chain in the territory is therefore possible at regional level in different sectors, so that territorial axes of development can be identified and, through digitalization, the establishment of the symbiosis is enabled through longitudinal collaborative clustering between the different links of the value chain, and cross-links between other value chains. All this is made possible due to the sensorization and processing offered by the digital twin of the value chain as a cyber-physical system, a surrogate model, and as open innovation.

The cause-oriented approaches (such as C2C) [88] determine a circular, eco-effective, and harmless metabolism, based on the idea that it is possible to conceive the products and industrial processes thereof such that resources never become waste but are kept in a loop for as long as possible, with a minimum loss of quality. The $\mathrm{C} 2 \mathrm{C}$ approach pursues the orientation towards the principles of the $\mathrm{CE}$ and obtains solutions to the causes from cyclicity, effectiveness (renewable energy), and toxicity (safe substances and materials). However, there are numerous criticisms of the C2C approach [89].

The framework that integrates effect-oriented techniques is represented by LCA and eco-innovation, under the criteria of eco-efficiency versus eco-effectiveness to mitigate impacts and damage from design. This approach also has its detractors: For example, Braungart et al. [90], who argue that LCA approaches are unsuitable for circularity measurement, since they claim that these approaches are inherently linear. The metabolism from eco-efficiency is therefore improved.

Based on the advantages provided by the two frameworks, the suitability of using both is identified. This is contrasted by various authors such as Bach [91] and Niero and Hauschild [92], who, on conducting an analysis on the products developed through $\mathrm{C} 2 \mathrm{C}$, conclude that LCA and C2C can and should be used as complementary tools. Scheepens [93] also confirms the suitability of LCA research for the $\mathrm{CE}$, especially when evaluating circular systems. 


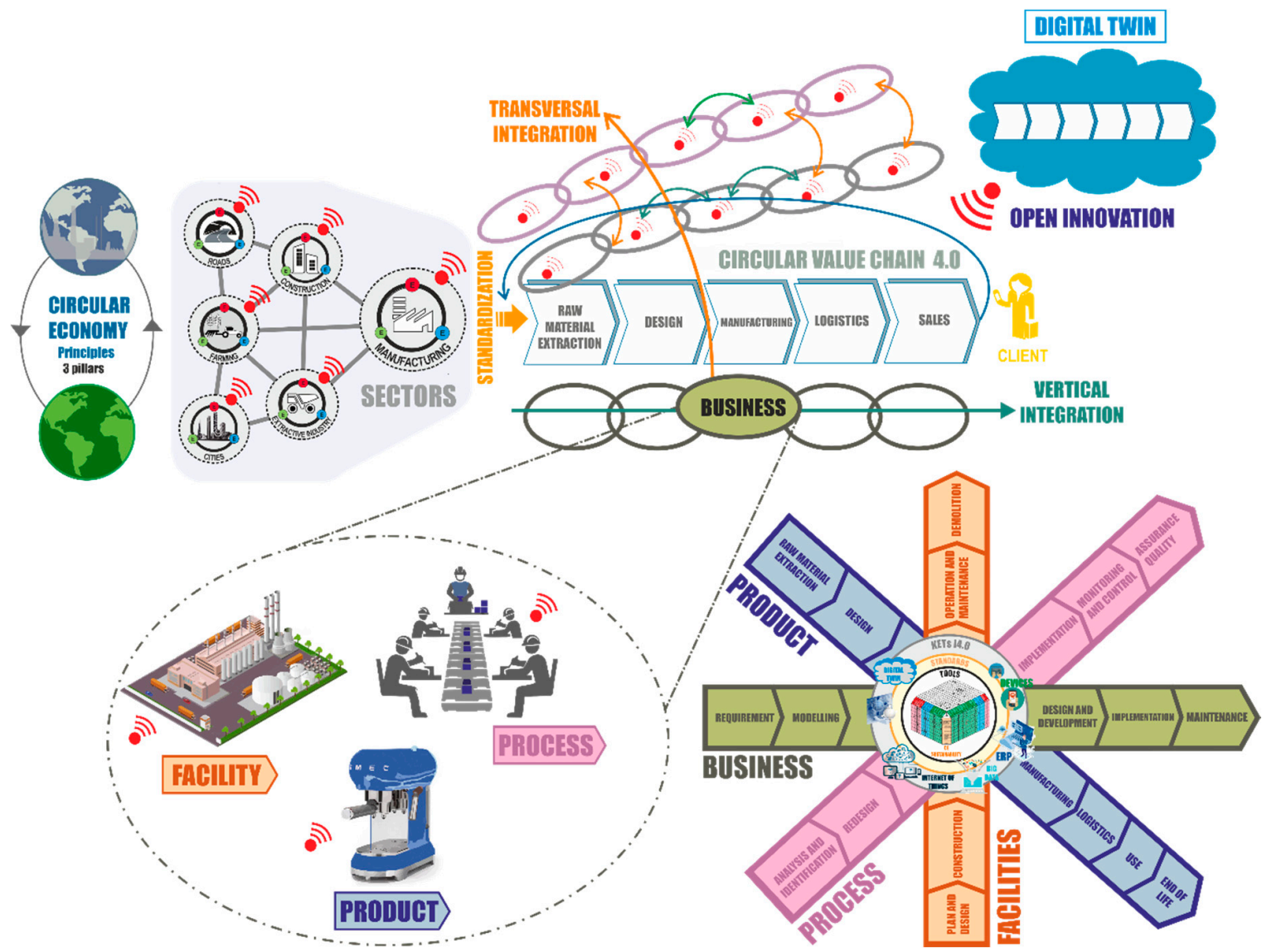

Figure 4. Characterization and standardization of the circular value chain 4.0.

Derived from the above, a framework is established for the deployment of the standardization of the $\mathrm{CE}$ under its conceptualization as a paradigm for the sustainability of the various regional sectors, starting at the value chain level, and rising up to the different levels of concretion, which determines a metabolism of appropriation of sustainable resources for the socio-ecological transition.

For various productive sectors, the circular value chain is established as the most aggregate form of productive activity, with the greatest impact on the metabolic rift, and it is therefore configured in the business design. The consideration of the circularity in the metabolism of the value chain is obtained by the circularity of each of the links that compose it as basic units of value creation. Under the previous considerations, each of the links of the circular value chain as a basic unit of value creation can be conceptualized as a product or value obtained, a process or activities of value creation, and as facilities or resources on which processes or products are developed. These three entities, together with the business entity, will be provided with their sustainable life cycle, for which they must have their toolbox as shown in Figure 5, their facilitating technology and their standards from the CE.

Developing this model, four dimensions of interest are considered such as: Product, process, facilities, and business. Figure 6 shows that each of these dimensions must be from the CE principles with the competition of rules for the $\mathrm{CE}$. The proposal to deploy the $\mathrm{CE}$ standardization framework would have a first level of strategy standards (CE strategy standards) of the incorporation of CE into companies from the life cycle engineering perspective, the establishment of a list of tools and techniques under the CE paradigm, from where the pillars of sustainability are deployed, and cause-oriented frameworks (covering techniques and tools such as C2C) and effect-oriented frameworks (integrating techniques and tools such as LCA), or the joint articulation in the search for a circular industrial metabolism 4.0. This enables various forms of business incorporation from the values, vision, mission, and competitiveness strategy of companies. The second level of standardization corresponds to CE standards aimed at the specific normalization of different techniques and tools of CE operational norms, 
embedded in CE strategies, integrated into lean production management systems, and articulated in the field of environmental (ISO 14001), economic (ISO 9001), and social (ISO 45001) management systems. All this standardization is integrated in the systems, products, and equipment designed with the frameworks proposed in the first level. Regarding the third level (CE maturity norms), this would correspond to the degree of maturity in the implementation of the $\mathrm{CE}$ in an organization through the incorporation of digital, organizational, and innovation KETs, to enable circular Industry 4.0 the greater reach and efficiency of the first and second levels. This would be carried out by incorporating not only the economic dimension into the key performance indicators (KPIs) of the processes, but also the environmental and social dimensions. These are integrated into a model of circular metabolisms associated with dashboards and surrogate models for real-time monitoring, and the control of the circularity of resources (metabolism associated) is integrated into the appropriation of productive or service activity. This process allows the digital transformation of sustainability for the sustainable metabolism connected in the organization.

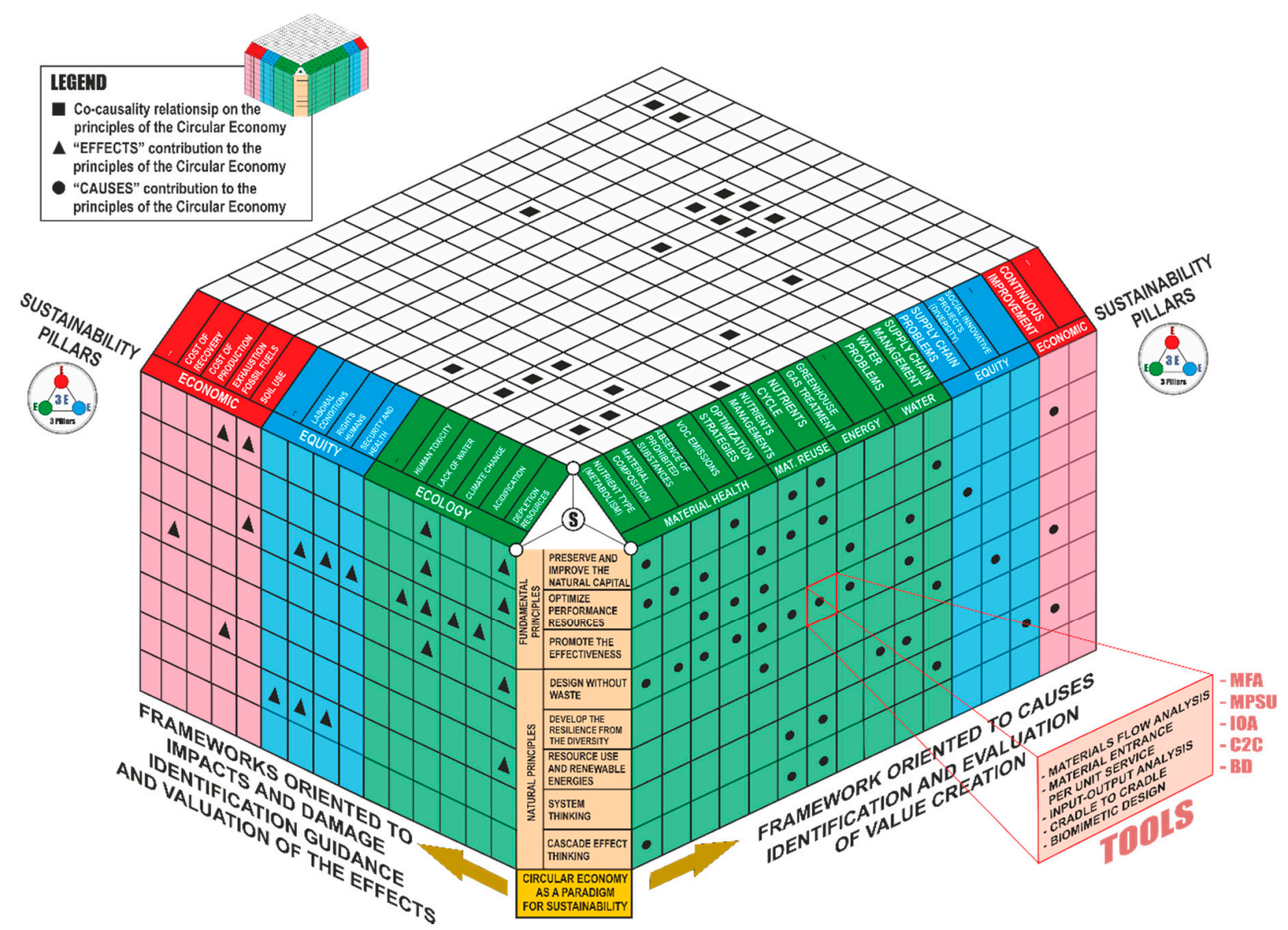

Figure 5. Integration matrix of frameworks, techniques, and tools in sustainability pillars from the circular economy paradigm.

Each entity (product, process, facilities, and business) is represented with its own life cycle. This refers to the flow of information and to the controls that exist in the early stage of product design and continues until the end of their life cycle.

In the case of a concurrent engineering project under Industry 4.0 in BIM and PLM environments, the life cycles of the circular business, product, process, and facilities and the standardization to be carried out by the corresponding entities correspond to the stages of their life cycle and the KETs. Each stage has a set of techniques and tools of the frameworks oriented to the causes or effects for each of the pillars of social, environmental, and economic sustainability in an integrated way. These have the objective of finding efficiency (in the use of materials, energy, and water), safety (use of non-toxic substances), and circularity of biological nutrients in the natursphere and of technicians in 
the technosphere. The characterization of these factors is carried out through KPIs or key indicators of sustainable performance, through KETs, monitor and control in the corresponding phase of the cycle, and are available in real time.

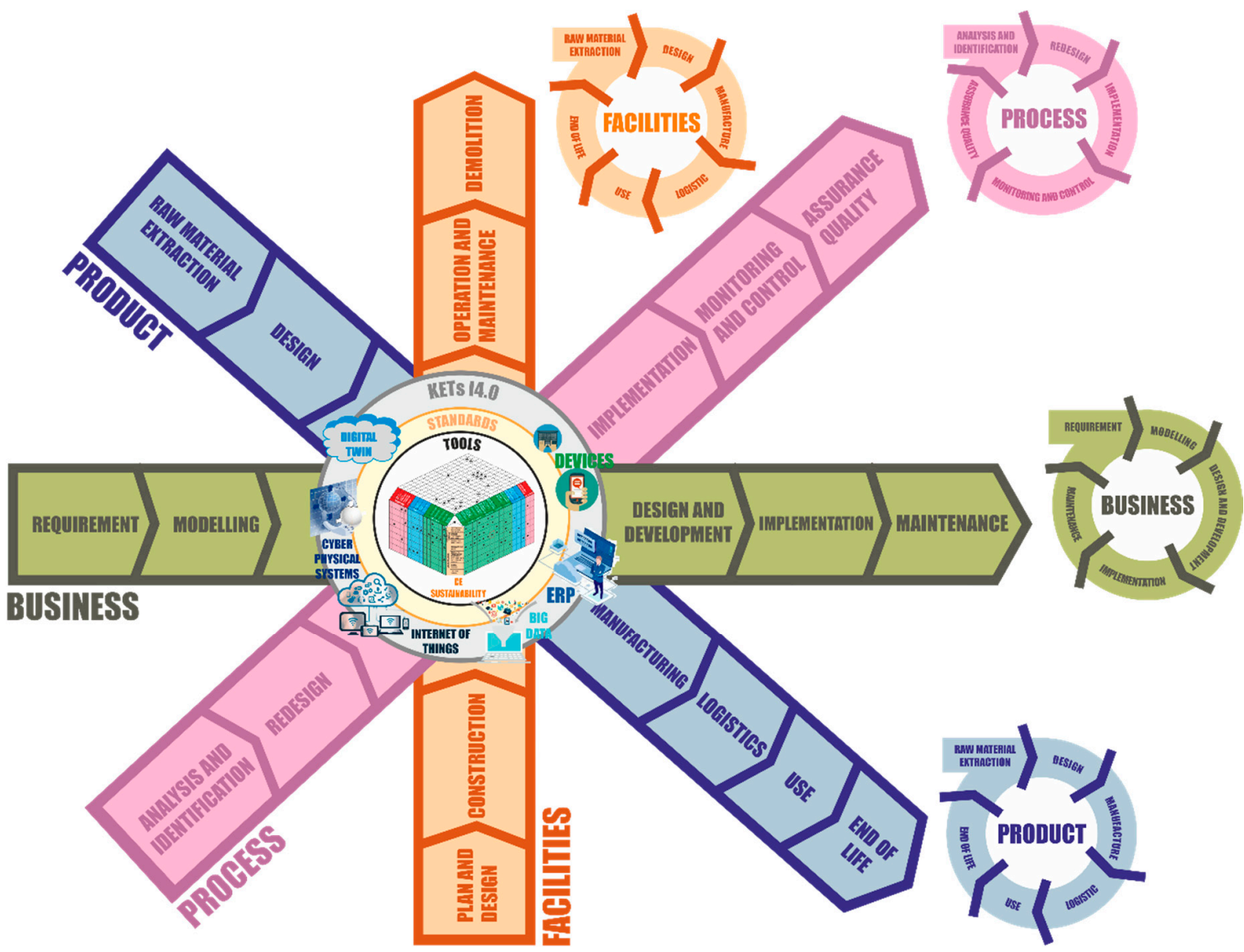

Figure 6. Integrated ecosystem for circular economy 4.0.

\section{Case Study}

The conceptual framework establishes the study throughout its life cycle of four entities that constitute the ecosystem of the $\mathrm{CE}$ and is shown in Figure 6: Business, product, process, and facility. All these entities are within the circular value chain. On selecting one entity, for example the "product", the field of study and the work context are studied as shown in Figure 7, where the transfer of knowledge from research to case study is shown. In this case, since it is impossible to process all the phases of its life cycle, only one phase is chosen as the phase of product design as shown in Figures 8 and 9. For this entity, tools, standards, KPIs, and KETs are established. For tools, the techniques and methods bottom-up and top-down in the design phase of a product and the matrix that structures the framework is shown in Figure 5. Once the general tools, KPIs, standards, and KETs have established its knowledge base, they can be particularized and discussed. For the design phase of any product, all the necessary information and the corresponding standards can be identified, thereby making it possible to stablish its relations with the pillars of sustainability and with the principles of the CE paradigm.

This section is divided into two parts. First, the case study is introduced in terms of the scope of study and work context, and the result of applying the proposed model at the level of product in the design phase is subsequently presented. A contribution is proposed in each of the analysed areas. 


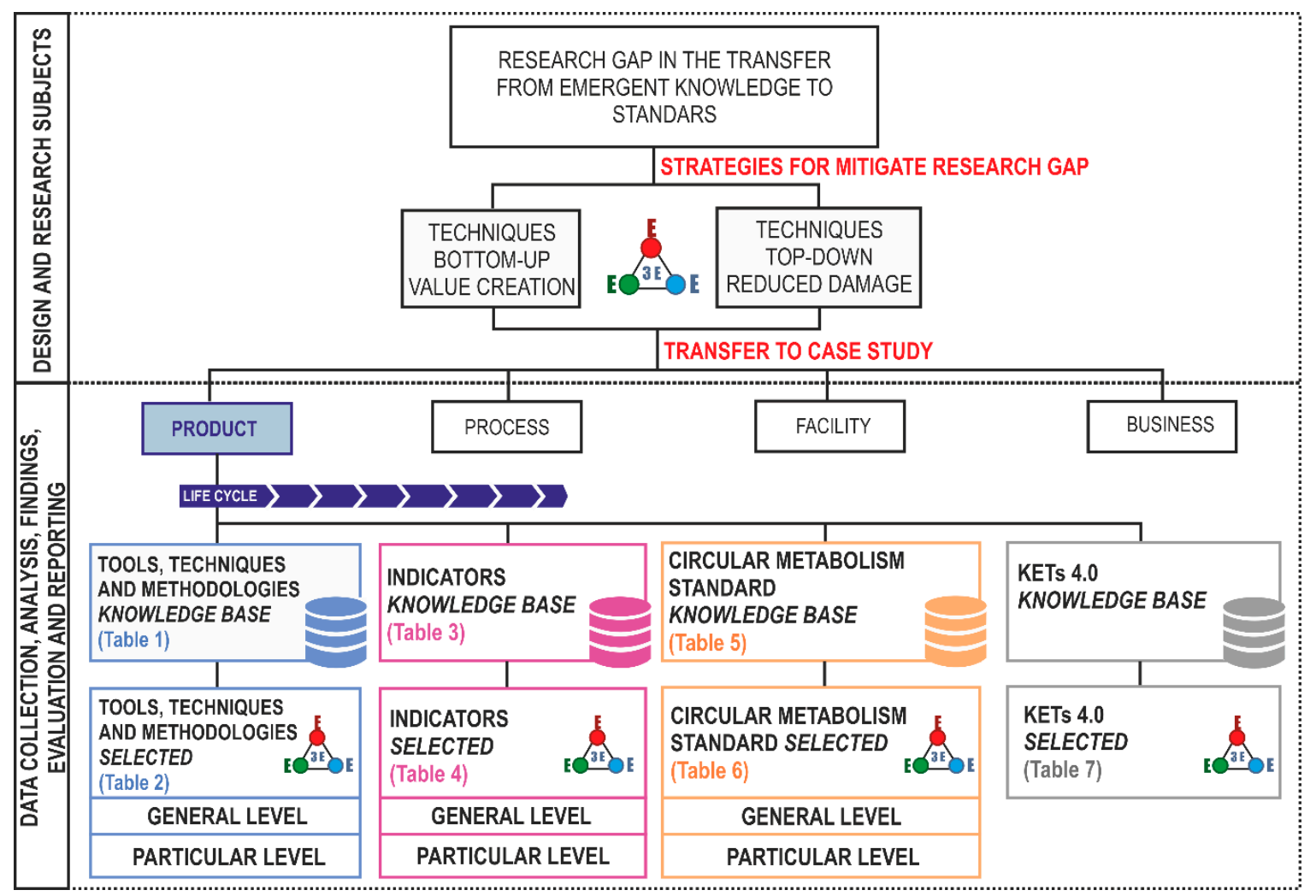

Figure 7. Logic model to evaluate the research process.

\subsection{Methodological Framework for a Product}

A case study of standardization of the $\mathrm{CE}$ is presented here to illustrate the proposed approach. The case study to be carried out shows the use of the proposed model at the product level. Figure 8 shows the phases of the life cycle of the product. The following conceptual diagram outlines the main phases of a CE model in a simplified way.

The phases for a circular product are interlinked, since the materials can be used in a cascade, such as when industry exchanges by-products, products are remanufactured, or when consumers choose product-service systems.

The CE seeks to make a more efficient use of resources and materials, for the best recycling of their value and raw materials. Reuse and remanufacturing provide good examples of the $\mathrm{CE}$, since they save a large proportion of the energy used in the original production, such as in the extraction of resources and further processing.

The development of the design of a product is shown in Figure 9. It proposes a study of four characteristic such as: (1) Tools to be used depending on triple bottom line contribution and added value or on the mitigation of the damage; (2) KPIs appropriate for this phase according to whether it is found at an economic, ecology, equity (3E) level; (3) existing and recommended standards for this phase; and (4) KETs 4.0 suitable for use at this stage of the life cycle.

In the next section, the framework is developed for the product, and strategies are conducted for the development of transversal and particular standards. Similarly, for the other elements of the ecosystem for circular economy 4.0 shown in Figure 6: Circular business, circular processes, and circular facilities, can be carried out on the same proposed methodological framework. 


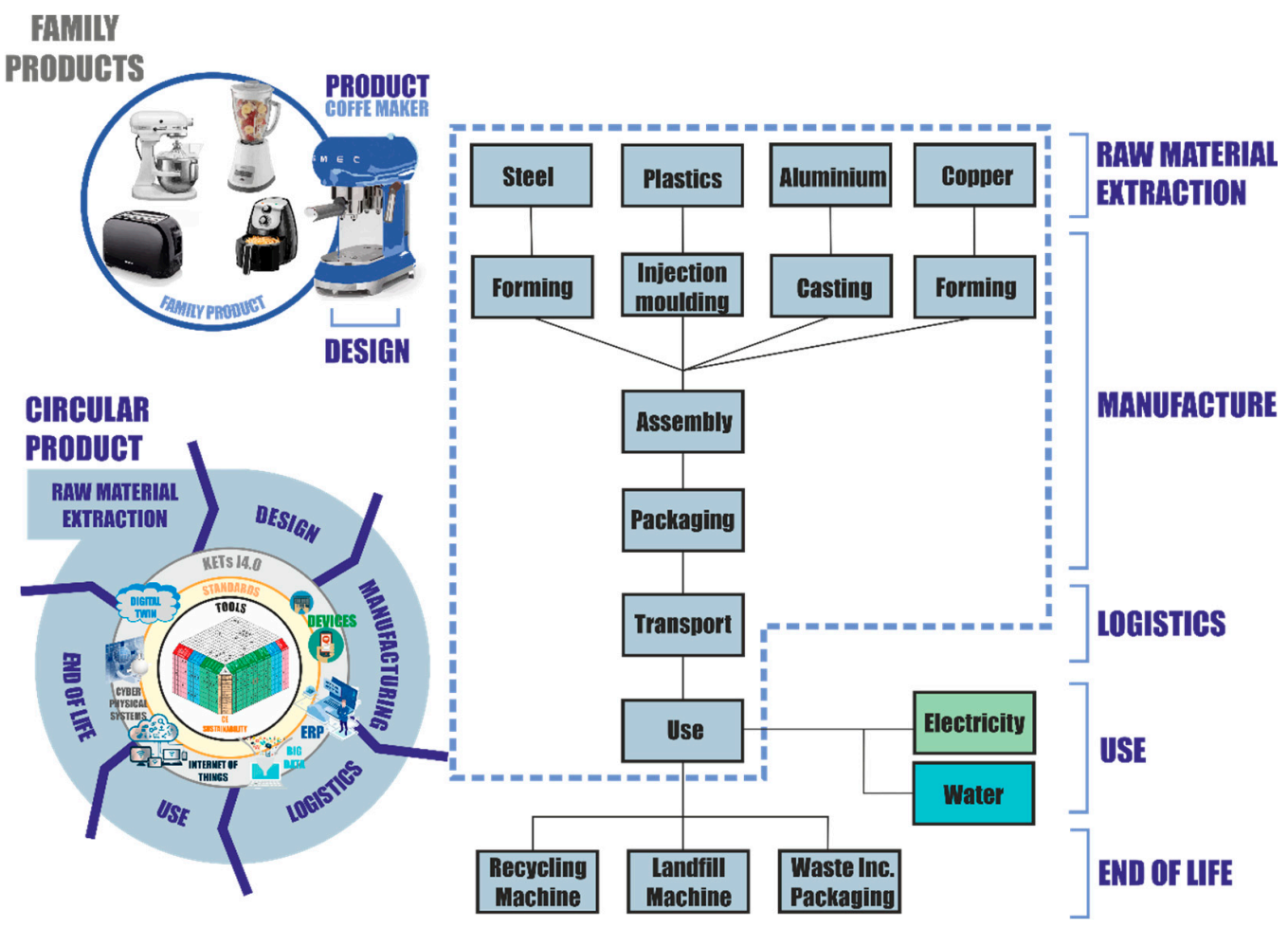

Figure 8. Life cycle for the development of a "Product".

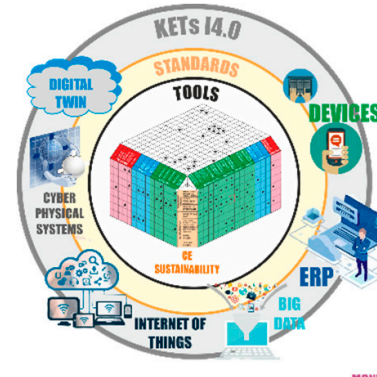

PRODUGT: Life Gycle Phase

\section{Gomponent level Structure level System level}
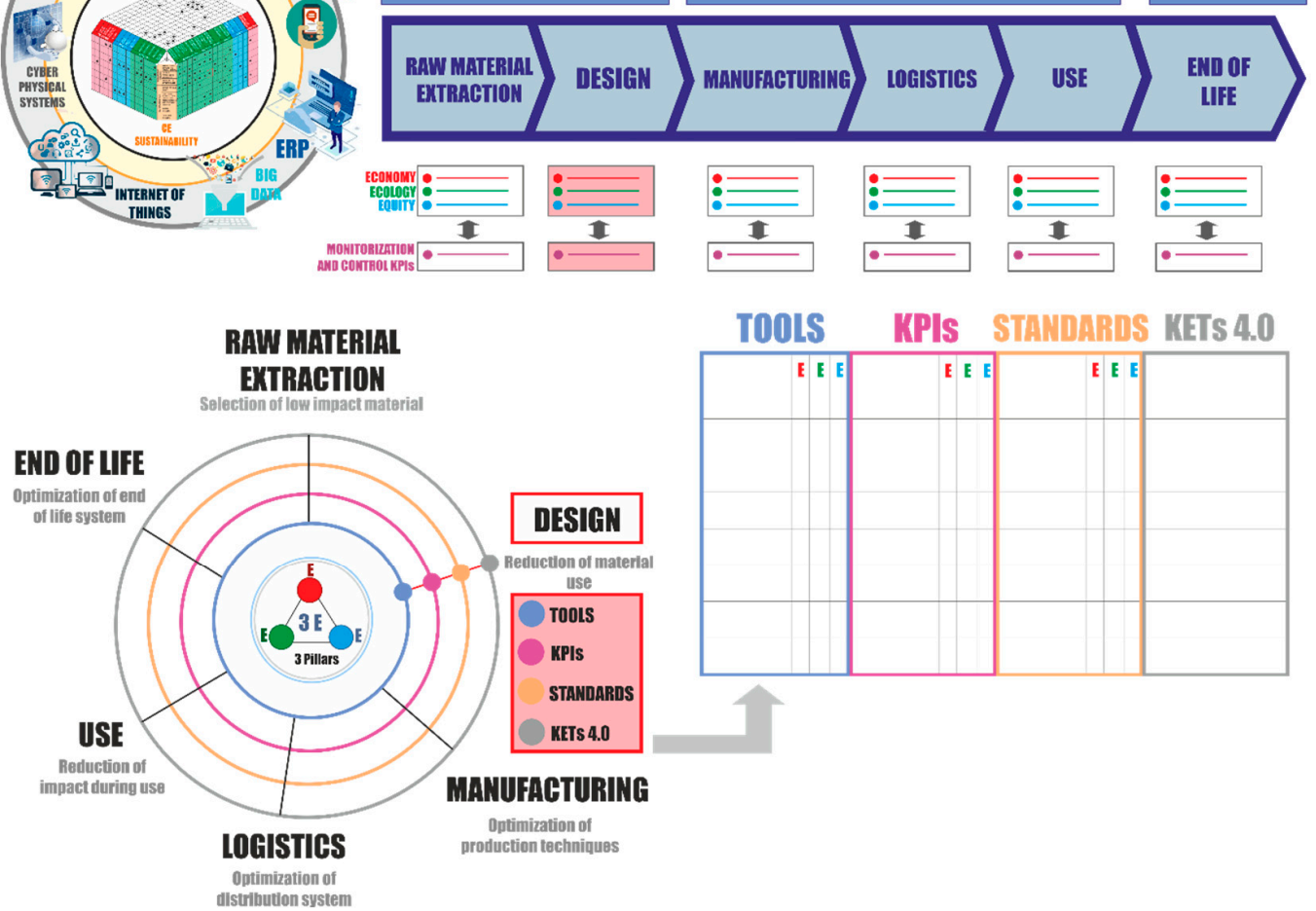

TOOLS KPIS STANDARDS KETS 4.0

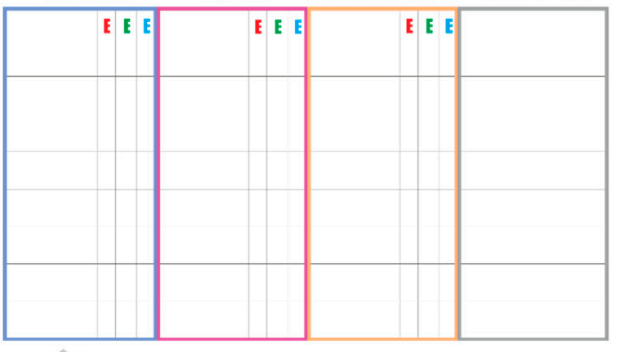

Figure 9. Development of circular economy 4.0 for a product.

\subsection{Result and Discussion}

Following the methodological framework reported in Figures 4 and 6, the result of the application for a product level in the design phase is presented in the subsequent sections. To this end, tools, KPIs, 
standards, and KETs are represented in the product life cycle. Their implementation is included in tables organized in terms of the life cycle of the product and the transversal and particular point of view. Each life cycle phase can be grouped into three levels as shown in Figure 9: Product component (micro-level): Raw material extraction and Design; product structure (meso-level): Manufacturing, logistics, and use; and product system (macro-level): End of life.

Similarly, considerations in the following sections can be applied for the other elements of the Ecosystem for Circular Economy 4.0 as shown in Figure 6: Circular business, circular processes, and circular facilities, which can be applied on the same proposed methodological framework.

\subsubsection{Product Design Phase for Tools}

Tools that are detailed in the section on the background of the literature and are characterized in this analysis shows that numerous tools can be found widely dispersed across the literature. Furthermore, it is difficult to ascertain which tool is appropriate for each case, and therefore this study offers an overview of the appropriate tools based on the principles of the CE, the pillars of sustainability, and on the creation of value or reduced damage. All this information is reflected in each of the cells of the matrix in Figure 5.

Table 1 summarizes the suitability of each tool (represented by " $\mathrm{X}^{\prime \prime}$ ) according to the proposed model, or toolbox. To this end, the tools are classified with strategies of the $\mathrm{CE}$, the three aspects of sustainability (Ecology, Economy, and Equity) and the contribution of value $(+)$ or reduction of damage (-).

Table 1. Tools in product design.

\begin{tabular}{|c|c|c|c|c|c|c|c|}
\hline \multirow{2}{*}{$\begin{array}{c}\text { Tools for Circular } \\
\text { Product: Design } \\
\text { Phase }\end{array}$} & \multirow{2}{*}{ Key } & \multirow{2}{*}{$\begin{array}{c}\text { CE } \\
\text { Principles * }\end{array}$} & \multicolumn{3}{|c|}{$\begin{array}{c}\text { Triple Bottom } \\
\text { Line (TBL) }\end{array}$} & \multirow{2}{*}{$\begin{array}{c}\text { Value } \\
\text { Creation } \\
\quad(+)\end{array}$} & \multirow{2}{*}{$\begin{array}{c}\text { Reduced } \\
\text { Damage } \\
(-)\end{array}$} \\
\hline & & & $\mathrm{E}$ & $\mathbf{E}$ & $\mathbf{E}$ & & \\
\hline Material Flow Analysis & MFA & $(1)(2)$ & $x$ & & & & $x$ \\
\hline Life Cycle Assessment & LCA & (1) (2) (3) & $x$ & & & & $x$ \\
\hline Material input per service unit & MIPSU & (1) (2) & $X$ & & & & $X$ \\
\hline Ecological rucksack & ER & (1) & $x$ & & & & $x$ \\
\hline Water circularity (water footprint) & WC & (2) & $x$ & & & & $x$ \\
\hline Longevity Indicator & LI & (2) & $x$ & & & & $x$ \\
\hline Input-Output Analysis & IOA & (2) & $x$ & $X$ & & & $x$ \\
\hline Ecological Networks Analysis & ENA & (1) (3) & $X$ & & & $x$ & \\
\hline Embedded Energy Analysis & EEA & (2) & $x$ & & & & $x$ \\
\hline Emergy Analysis & EA & $(2)$ & $X$ & & & & $X$ \\
\hline Exergy Analysis & ExA & (2) & $x$ & & & & $x$ \\
\hline Analysis of Social Exergy & ASEx & (2) & $x$ & & $X$ & & $x$ \\
\hline Sankey diagram & SD & (2) & $x$ & & & & $x$ \\
\hline Substance Flow Analysis & SFA & (2) & $x$ & & & & $x$ \\
\hline Substance Analysis from C2C & SA & (2) & $X$ & & & $x$ & \\
\hline Bioinspired or Biomimetic Design & $\mathrm{BD}$ & (1) & $x$ & & & $x$ & \\
\hline Life cycle cost analysis & LCCA & (2) (3) & & $X$ & & & $X$ \\
\hline Economic Network Analysis & EcNA & (2) (3) & & $x$ & & $X$ & \\
\hline Cost-Benefit Analysis & CBA & (2) & & $x$ & $X$ & & $x$ \\
\hline Eco-costs/Relationship & Ec & $(2)$ & $X$ & $x$ & & & $x$ \\
\hline Eco-efficient Value Creation & $\mathrm{EcVC}$ & (1) (2) & & $X$ & & & $x$ \\
\hline Actor Network Theory & ANT & (1) (2) & & $X$ & $x$ & $x$ & $x$ \\
\hline Socio-constructivism & SC & (1) (3) & & & $x$ & $x$ & \\
\hline Social Life Cycle Assessment & S-LCA & (2) (3) & & & $x$ & & $x$ \\
\hline Social Network Analysis (SNA) & SNA & (1) (2) & & & $X$ & & $X$ \\
\hline Cradle to Cradle (C2C) & $\mathrm{C} 2 \mathrm{C}$ & $(1)(2)(3)$ & $X$ & $X$ & $X$ & $X$ & $x$ \\
\hline
\end{tabular}

* The Circular Economy (CE) principles considered are: (1) Preserve and improve natural capital; (2) optimize resource performance; and (3) enhance effectiveness. 
Subsequent to the previous analysis, the appropriate tools for the design and development of the product include those shown in Table 2.

Table 2. Implementation of tools in product life cycle "Design".

\begin{tabular}{|c|c|c|c|c|c|}
\hline \multicolumn{2}{|c|}{ Product Component Level } & \multicolumn{3}{|c|}{ Product Structure Level } & Product System Level \\
\hline Raw material extraction & Design & Manufacturing & Logistics & Use & End of life \\
\hline \multicolumn{6}{|c|}{ Transversal tools $(\mathrm{E}, \mathrm{E}, \mathrm{E})$ * } \\
\hline $\begin{array}{r}\text { Mat } \\
\text { Embedded Er }\end{array}$ & $\begin{array}{l}\text { Ec } \\
\text { al Flow } A \\
\text { sy Analy }\end{array}$ & $\begin{array}{l}\text { fe Cycle Assessm } \\
\text { Cradle to Cradle } \\
\text { gical Network Ar } \\
\text { lysis (MFA)/ Sub } \\
\text { (EEA)/ Emergy A }\end{array}$ & $\begin{array}{l}(\mathrm{LCA})(\mathrm{E}, \\
2 \mathrm{C})(\mathrm{E}, \mathrm{E}, \mathrm{z} \\
\text { ysis (ENA) } \\
\text { ace Flow A } \\
\text { lysis (EA)/ }\end{array}$ & $\begin{array}{l}\text { E) } \\
\text { sis }(S \\
\text { gy A }\end{array}$ & $\begin{array}{l}(\mathrm{E}, \mathrm{E}, \mathrm{E}) \\
\text { ysis }(\mathrm{ExA})(\mathrm{E}, \mathrm{E}, \mathrm{E})\end{array}$ \\
\hline \multicolumn{6}{|c|}{ Particular tools $(\mathrm{E}, \mathrm{E}, \mathrm{E})$ * } \\
\hline \multicolumn{2}{|c|}{$\begin{array}{l}\text { - Bioinspired or biomimetic design } \\
\text { - Material input per service unit } \\
\text { - Socio-constructivism } \\
\text { - Life cycle cost analysis }\end{array}$} & \multicolumn{3}{|c|}{$\begin{array}{l}\text { - Actor Network Theory } \\
\text { - Cost-benefit analysis } \\
\text { - Social Network Analysis } \\
\text { - Eco-efficient Value Creation }\end{array}$} & $\begin{array}{l}\text { - Input-Output Analysis } \\
\text { - Longevity indicator } \\
\text { - Social Life Cycle Assessment }\end{array}$ \\
\hline
\end{tabular}

\subsubsection{Product Design Phase for Key Performance Index}

The monitoring and evaluation of sustainability with the Key Performance Index (KPI) (Ecology, Economy, and Equity) must be carried out and are shown in Table 3.

These indicators aim to monitor and control the information with measurable parameters that can be adapted according to the needs of the product, business, process, and facility. This measurable information requires the help of emerging technologies or digital enablers.

Table 3. KPIs in product design.

\begin{tabular}{|c|c|c|c|c|}
\hline \multirow{2}{*}{ Id. } & \multirow{2}{*}{ Indicator for Circular Product: Design Phase } & \multicolumn{3}{|c|}{ Triple Bottom Line (TBL) * } \\
\hline & & $\mathrm{E}$ & E & E \\
\hline KPI01 & Total weight of the use of raw material in the product $[\mathrm{kg}]$ & $\mathrm{X}$ & & \\
\hline KPI02 & Raw material use efficiency in the packaging [\%] & $x$ & & \\
\hline KPI03 & Total weight of the packaging material used [ $\mathrm{kg}$ material] & $\mathrm{x}$ & & \\
\hline KPI04 & Mass of restricted material used $[\mathrm{kg}]$ & $\mathrm{x}$ & & \\
\hline KPI05 & Energy consumption $[\mathrm{kWh}]$ & $x$ & & \\
\hline KPI06 & Use of renewable energy [MJ eq] & $\mathrm{x}$ & & \\
\hline KPI07 & Number of projects carried out [n] & & $\mathrm{x}$ & $\mathrm{X}$ \\
\hline KPI08 & CAD-drawing received on time [weeks] & & $\mathrm{x}$ & \\
\hline KPI09 & On-time delivery [weeks] & & $\mathrm{x}$ & \\
\hline KPI10 & Consideration of real costs: externalities $[€]$ & & $\mathrm{x}$ & \\
\hline KPI11 & Efficiency in energy use $[\%]$ & $\mathrm{x}$ & & \\
\hline KPI12 & Total amount of water consumed $\left[\mathrm{m}^{3}\right]$ & $\mathrm{x}$ & & \\
\hline KPI13 & Water use efficiency [\%] & $\mathrm{x}$ & & \\
\hline KPI14 & Returned material to the product $[\%]$ & $\mathrm{x}$ & & \\
\hline KPI15 & Consumables recovered $[\%]$ & $\mathrm{x}$ & & \\
\hline KPI16 & Used packaging material recovered [\%] & $\mathrm{x}$ & & \\
\hline KPI17 & Used raw material/recovered scrap parts [\%] & $\mathrm{x}$ & & \\
\hline KPI18 & Recovered energy returned to the product [\%] & $\mathrm{x}$ & & \\
\hline KPI19 & Use of recycled water returned to the product [\%] & $x$ & & \\
\hline KPI20 & Waste generation intensity $[\mathrm{kg} / \mathrm{h}]$ & $\mathrm{x}$ & & \\
\hline KPI21 & Amount of greenhouse gases generated $\left[\mathrm{kgCO}_{2}\right]$ & $\mathrm{x}$ & & \\
\hline KPI22 & Biological nutrients, supra-recycled technicians $[\mathrm{kg}]$ & $x$ & $\mathrm{x}$ & \\
\hline KPI23 & Learning cost $[€]$ & & $\mathrm{x}$ & $\mathrm{x}$ \\
\hline KPI24 & Operating costs $[€]$ & & $\mathrm{x}$ & \\
\hline KPI25 & Patent application [n] & & & $\mathrm{X}$ \\
\hline KPI26 & Value added and job [projects realized/month] & & & $\mathrm{X}$ \\
\hline
\end{tabular}


Table 3. Cont.

\begin{tabular}{|c|c|c|c|c|}
\hline \multirow{2}{*}{ Id. } & \multirow{2}{*}{ Indicator for Circular Product: Design Phase } & \multicolumn{3}{|c|}{ Triple Bottom Line (TBL) * } \\
\hline & & E & $\mathrm{E}$ & $\mathrm{E}$ \\
\hline KPI27 & Corporate Social Responsibility (CSR Brand value) & & $X$ & $X$ \\
\hline KPI28 & Worker safety and health $\left[\mathrm{n}^{\mathrm{o}}\right.$ accident $]$ & & & $X$ \\
\hline KPI29 & Adaptation of jobs for people with special needs & & & $X$ \\
\hline KPI30 & Worker efficiency (Ratio of personal work time/defined assistance time) & & $X$ & $X$ \\
\hline
\end{tabular}

* (Ecology, Economy, and Equity).

These three aspects are considered in order to reflect the inputs and outputs from the environmental perspective [94]. The evaluation and monitoring of social aspects must be considered from the point of view of the stakeholders [95].

The evaluation of the economic dimension at the product design level can be considered based on the quality and efficiency in the design process, and is represented by " $X$ ".

Contributions to the most appropriate indicators for product design and development are those shown in Table 4.

Table 4. Implementation of KPIs in product life cycle "Design".

\begin{tabular}{|c|c|c|c|c|}
\hline \multicolumn{2}{|c|}{ Product Component Level } & \multicolumn{2}{|c|}{ Product Structure Level } & \multirow{2}{*}{$\begin{array}{c}\text { Product System Level } \\
\text { End of life }\end{array}$} \\
\hline Raw material extraction & Design & Manufacturing & \begin{tabular}{|l|l} 
Logistics \\
\end{tabular} & \\
\hline \multicolumn{5}{|c|}{ Transversal KPIs (E, E, E) * } \\
\hline \multicolumn{5}{|c|}{$\begin{array}{c}\text { Raw material use efficiency in product [\%] (E, E, E) } \\
\text { Energy consumption [kWh] (E, E, E) } \\
\text { Water use efficiency [\%] (E, E, E) } \\
\text { Corporate Social Responsibility (CSR Brand value) (E, E, E) } \\
\text { Patent application [n] (E, E, E) }\end{array}$} \\
\hline \multicolumn{5}{|c|}{ Particular KPIs $(\mathrm{E}, \mathrm{E}, \mathrm{E}) *$} \\
\hline \multicolumn{2}{|c|}{$\begin{array}{l}\text { - Number of projects carried out [n] } \\
\text { - Learning cost [€] } \\
\text { - Worker efficiency [\%] } \\
\text { - CAD-drawing received on time [weeks] }\end{array}$} & \multicolumn{2}{|c|}{$\begin{array}{l}\text { On-time delivery [weeks] } \\
\text { - Operating costs [€] } \\
\text { - Adaptation of jobs for people with } \\
\text { special needs [competency profile] } \\
\text { - Amount of greenhouse gases } \\
\text { generated }\left[\mathrm{kgCO}_{2}\right] \\
\text { — Worker safety and health } \\
{\left[\mathrm{n}^{\circ} \text { accident] }\right.}\end{array}$} & $\begin{array}{l}\text { - Efficiency in the packaging [\%] } \\
\text { - Waste generation intensity }[\mathrm{kg} / \mathrm{h}] \\
\text { - Consumables recovered }[\%] \\
\text { - Biological nutrients, } \\
\text { supra-recycled technicians }[\mathrm{kg}] \\
\text { - Waste generation intensity }[\mathrm{kg} / \mathrm{h}]\end{array}$ \\
\hline
\end{tabular}

\subsubsection{Product Design Phase for Standard}

In order to make the $\mathrm{CE}$ a reality, a long-term commitment is required at all levels, from member states, regions and cities, to businesses and citizens.

Derived from the study of the existing normative, it can be observed that a major effort is being exerted to strive to normalize the $\mathrm{CE}$ but that even knowledge is very dispersed. There are many standards that try to solve different aspects of sustainable products as shown in Table 5.

These standards are classified according to type of standard: Transversal (T) or particular (P), and the adequacy of each standard (represented by " $X$ ") according to the sustainability aspects of the proposed model (Ecology, Economy, and Equity) and value creation (+) or reduced damage (-).

In order to carry out a consensus among the different agents involved in the project, it would be necessary to establish transverse and particular regulations at each level. The objective is to help the implementation of CE projects with the use of standards that establish the requirements, tools, and indicators to control each life cycle phase and to enable technologies that add value to this new era of intelligent industrial systems. In Table 6, the principal standards for product design have been considered.

Moreover, certain appropriate tools that are defined for their keys are established for transversal standards, which can be used for future projection in the new standards. 
Table 5. Standards for sustainability.

\begin{tabular}{|c|c|c|c|c|c|c|}
\hline \multirow{2}{*}{ Standards for Circular Product: Design Phase } & \multirow{2}{*}{ Type } & \multicolumn{3}{|c|}{$\begin{array}{l}\text { Triple Bottom } \\
\text { Line (TBL) }\end{array}$} & \multirow{2}{*}{$\begin{array}{c}\text { Value } \\
\text { Creation (+) }\end{array}$} & \multirow[t]{2}{*}{$\begin{array}{c}\text { Reduced } \\
\text { Damage (-) }\end{array}$} \\
\hline & & $\mathrm{E}$ & $\mathrm{E}$ & $\mathrm{E}$ & & \\
\hline ISO/TC Circular Economy & $\mathrm{T}$ & $\mathrm{X}$ & $\mathrm{x}$ & $x$ & $\mathrm{x}$ & $\mathrm{x}$ \\
\hline ISO/TC 207 Environmental Management & $\mathrm{T}$ & $\mathrm{x}$ & & & $\mathrm{x}$ & \\
\hline CEN/CLC/JTC 10 Efficiency in the use of materials & $\mathrm{T}$ & $\mathrm{x}$ & $\mathrm{x}$ & & $\mathrm{x}$ & $\mathrm{x}$ \\
\hline $\begin{array}{l}\text { PNE-prEN IEC 62959:2018. Environmentally } \\
\text { Conscious Desion (ECD) }\end{array}$ & $\mathrm{T}$ & $x$ & & & $x$ & \\
\hline ISO 8887-1:2017 Technical product documentation & $\mathrm{T}$ & & $\mathrm{x}$ & $\mathrm{x}$ & $x$ & \\
\hline $\begin{array}{l}\text { ISO 10303-the STEP Standard for Product Data } \\
\text { Exchange }\end{array}$ & $\mathrm{T}$ & & $x$ & & $x$ & \\
\hline $\begin{array}{l}\text { ISO/TC 176. Quality management and quality } \\
\text { assurance }\end{array}$ & $\mathrm{T}$ & & $x$ & & $x$ & \\
\hline ISO/TC 279. Innovation management & $\mathrm{T}$ & & $\mathrm{x}$ & & $\mathrm{x}$ & \\
\hline ISO/TC 324. Sharing Economy & $\mathrm{T}$ & & $\mathrm{x}$ & & $\mathrm{x}$ & $\mathrm{x}$ \\
\hline Directive 2009/125/CE (RD 187/2011) Eco-design & $\mathrm{P}$ & $x$ & & & & $\mathrm{x}$ \\
\hline $\begin{array}{l}\text { ANSI/AAMI HE74:2001 Human Factors Design } \\
\text { Process }\end{array}$ & $\mathrm{T}$ & & & $x$ & $x$ & $x$ \\
\hline $\begin{array}{l}\text { ISO/TC 260. Human Resource Management } \\
\text { (ISO 30400, ISO 30405, ISO 30408, ISO 30409) }\end{array}$ & $\mathrm{T}$ & & & $x$ & $X$ & \\
\hline $\begin{array}{l}\text { ISO/TC 283. Occupational health and safety } \\
\text { management } \\
\text { (ISO 45001:2018) }\end{array}$ & $\mathrm{T}$ & & & $x$ & & $\mathrm{x}$ \\
\hline $\begin{array}{l}\text { ISO/TC159/SC4. Ergonomics of human-system } \\
\text { interaction }\end{array}$ & $\mathrm{T}$ & & & $x$ & & $\mathrm{x}$ \\
\hline M/495 Energy efficiency ErP & $\mathrm{P}$ & & $\mathrm{x}$ & & & $\mathrm{x}$ \\
\hline $\begin{array}{l}\text { IEC/TC 111. Environmental standardization for } \\
\text { electrical and electronic products and systems }\end{array}$ & $\mathrm{P}$ & $\mathrm{x}$ & & & & $x$ \\
\hline $\begin{array}{l}\text { UNE-EN } 62430 \text { Ecological design of electrical and } \\
\text { electronic products }\end{array}$ & $\mathrm{P}$ & $\mathrm{x}$ & & & & $x$ \\
\hline Cradle to Cradle Certified ${ }^{\mathrm{TM}}$ Product Standard & $\mathrm{P}$ & $\mathrm{x}$ & & & $\mathrm{x}$ & $\mathrm{X}$ \\
\hline $\begin{array}{l}\text { ASTM D6400-04 Standard specification for } \\
\text { compostable plastics. }\end{array}$ & $\mathrm{P}$ & $x$ & & & & $x$ \\
\hline $\begin{array}{l}\text { UNE-EN 13428. Containers and packaging. } \\
\text { Specific requirements for manufacturing and } \\
\text { composition. Prevention by reduction in origin }\end{array}$ & $\mathrm{P}$ & $x$ & & & $x$ & $\mathrm{x}$ \\
\hline $\begin{array}{l}\text { Directive 2008/98/EC Waste Framework Directive// } \\
\text { protect the environment and human health }\end{array}$ & $\mathrm{T}$ & $\mathrm{x}$ & & $\mathrm{x}$ & & $x$ \\
\hline $\begin{array}{l}\text { UNE-CEN ISO/TS } 14027 \text { Environmental labels } \\
\text { and declarations. Development of product } \\
\text { category rules }\end{array}$ & $\mathrm{P}$ & $x$ & & & $x$ & \\
\hline $\begin{array}{l}\text { ISO 14001. Environmental management systems. } \\
\text { Requirements with guidance for use }\end{array}$ & $\mathrm{T}$ & $x$ & & & $x$ & \\
\hline $\begin{array}{l}\text { ISO 14004. Environmental management } \\
\text { systems-General guidelines on implementation }\end{array}$ & $\mathrm{T}$ & $\mathrm{x}$ & & & $x$ & \\
\hline $\begin{array}{l}\text { ISO 14006. Environmental management } \\
\text { systems-Guidelines for incorporating eco-design } \\
\text { ISO 14015. Environmental }\end{array}$ & $\mathrm{P}$ & $x$ & & & $\mathrm{x}$ & \\
\hline $\begin{array}{l}\text { management-Environmental assessment of sites } \\
\text { and organizations (EASO) }\end{array}$ & $\mathrm{T}$ & $\mathrm{x}$ & & & $x$ & \\
\hline $\begin{array}{l}\text { ISO 14020-14025. Environmental labels and } \\
\text { declarations }\end{array}$ & $\mathrm{P}$ & $x$ & & & $x$ & \\
\hline $\begin{array}{l}\text { ISO/NP 14030. Green bonds. Environmental } \\
\text { performance of nominated projects and assets; } \\
\text { discussion of post-production environmental } \\
\text { assessment }\end{array}$ & $\mathrm{T}$ & $\mathrm{x}$ & & & & $x$ \\
\hline $\begin{array}{l}\text { ISO 14031. Environmental } \\
\text { management-Environmental performance } \\
\text { evaluation-Guidelines }\end{array}$ & $\mathrm{T}$ & $x$ & & & $X$ & $x$ \\
\hline
\end{tabular}


Table 5. Cont.

\begin{tabular}{|c|c|c|c|c|c|c|}
\hline \multirow{2}{*}{ Standards for Circular Product: Design Phase } & \multirow{2}{*}{ Type } & \multicolumn{3}{|c|}{$\begin{array}{l}\text { Triple Bottom } \\
\text { Line (TBL) }\end{array}$} & \multirow{2}{*}{$\begin{array}{l}\text { Value } \\
\text { Creation (+) }\end{array}$} & \multirow[t]{2}{*}{$\begin{array}{c}\text { Reduced } \\
\text { Damage (-) }\end{array}$} \\
\hline & & $\mathrm{E}$ & E & E & & \\
\hline $\begin{array}{l}\text { ISO } 14040 \text { to } 14049 \text {. Environmental } \\
\text { management-Life cycle assessment; discussion } \\
\text { of pre-production planning and environment goal } \\
\text { setting. }\end{array}$ & $\mathrm{T}$ & $x$ & & & $x$ & $x$ \\
\hline $\begin{array}{l}\text { ISO 14050. Environmental } \\
\text { management-Vocabulary; terms and definitions } \\
\text { ISO/TR 14062. Environmental }\end{array}$ & $\mathrm{T}$ & $x$ & & & $x$ & \\
\hline $\begin{array}{l}\text { management-Integrating environmental aspects } \\
\text { into product design and development }\end{array}$ & $\mathrm{T}$ & $x$ & & & $x$ & $x$ \\
\hline $\begin{array}{l}\text { ISO 14063. Environmental management. } \\
\text { Environmental communication. Guidelines and } \\
\text { examples }\end{array}$ & $\mathrm{T}$ & $x$ & & $x$ & $x$ & \\
\hline $\begin{array}{l}\text { ISO 14064. Greenhouse gases; measuring, } \\
\text { quantifying, and reducing greenhouse gas } \\
\text { emissions }\end{array}$ & $\mathrm{T}$ & $X$ & & & & $x$ \\
\hline $\begin{array}{l}\text { ISO 9001:2015. Quality Management Systems } \\
\text { (QMS). Requirements. }\end{array}$ & $\mathrm{T}$ & & $x$ & & $x$ & $x$ \\
\hline $\begin{array}{l}\text { ISO 9004:2008. Guidelines for performance } \\
\text { improvement. }\end{array}$ & $\mathrm{T}$ & & $X$ & & $x$ & $x$ \\
\hline $\begin{array}{l}\text { ISO 10006. Quality management. Guidelines to } \\
\text { quality management in projects }\end{array}$ & $\mathrm{T}$ & & $x$ & & $x$ & \\
\hline $\begin{array}{l}\text { ISO 19011. Guidelines for quality management } \\
\text { systems auditing and environmental management } \\
\text { systems auditing }\end{array}$ & $\mathrm{T}$ & & $x$ & & $x$ & $x$ \\
\hline ISO/IEC 27001. Information security management & $\mathrm{T}$ & & $X$ & $X$ & $X$ & \\
\hline ISO 50001. Energy Audit & $\mathrm{T}$ & $X$ & $x$ & & & $X$ \\
\hline
\end{tabular}

The standards that should be implemented at the product level for its definition from the perspective of the CE, are shown in Table 6.

Table 6. Implementation of standards in product life cycle "Design".

\begin{tabular}{|c|c|c|c|c|c|}
\hline \multicolumn{2}{|c|}{ Product Component Level } & \multicolumn{3}{|c|}{ Product Structure Level } & \multirow{2}{*}{$\begin{array}{c}\text { Product System Level } \\
\text { End of life }\end{array}$} \\
\hline Raw material extraction & Design & Manufacturing & Logistics & Use & \\
\hline \multicolumn{6}{|c|}{ Transversal Standards (E, E, E) * } \\
\hline \multicolumn{6}{|c|}{$\begin{array}{c}\text { Bioinspired Metabolism Principles (E, E, E) (BD, LCA, C2C, ENA, EA, SNA) } \\
\text { Circular Metabolism Material (E, E, E) (MFA, MIPSU, ER, SFA, IOA, SA) } \\
\text { Circular Metabolism Water (E, E, E) (WC, LI, SA) } \\
\text { Circular Metabolism Energy (E, E, E) (EEA, EA, ExA, ASEx, SD) } \\
\text { Circular Metabolism Toxicity (E, E, E) (SFA, SA, C2C) } \\
\text { Circular Industrial Symbiosis (E, E, E) (ANT, ENA, SNA) } \\
\text { Circular Metabolism Supplier System (E, E, E) (ENA, LCCA, EcNA) } \\
\text { Circular adaptation of Standard for Product Data Exchange-ISO } 10303 \text { (E, E, E) }\end{array}$} \\
\hline \multicolumn{6}{|c|}{ Particular Standards (E, E, E) * } \\
\hline $\begin{array}{l}\text { - Design for innovative conc } \\
\text { - Design for Dematerializati } \\
\text { - Design for Functional com } \\
\text { - Design for Easier mainten }\end{array}$ & $\begin{array}{l}\text { nent optimization } \\
\text { ne and repair }\end{array}$ & $\begin{array}{l}\text { - Design for Moc } \\
\text { - Design for Opt } \\
\text { - Design for Effic } \\
\text { - Design for Lear }\end{array}$ & $\begin{array}{l}\text { product str } \\
\text { tion produ } \\
\text { logistics } \\
\text { aufacturing }\end{array}$ & hniques & $\begin{array}{l}\text { - Design for Share use of the product } \\
\text { - Design for Reuse of the product } \\
\text { - Design for Remanufacturing of } \\
\text { product } \\
\text { - Design for Recycling of materials }\end{array}$ \\
\hline
\end{tabular}

The product can be fully defined by its circularity, life cycle phases, tools and KPI indicators and all aspects of sustainability (economic, social, and environmental). For all this, it is necessary to employ new technologies that support and facilitate the technological implementation of all the knowledge generated. 


\subsubsection{Product Design Phase for Key Enabling Technologies (KETs)}

The aim is the integration of the use of KETs into standards derived from Industry 4.0 and technological implementation.

In order to optimize and extend the life of fixed assets, the ecosystem design is virtualised, and digital twins of assets are created to increase structural integrity and to prototype new lean structural designs cross functional workflows are enabled to connect traditionally siloed processes and to provide an integrated view of an asset throughout its lifecycle. Operations data is integrated for the establishment of data aggregation standards and secure drilling data integration platforms are developed by collaborating with vendors. The edges are analysed by using edge analytics to run linear as well as non-linear performance analytics on systems and key operations on the platform. Mechanizing and automating equipment. Safety is addressed and productivity is increased by mechanizing and automating tasks. Platforms are robotized or key offshore operations are designed for robot-only interventions. Complex parts are crafted. Downtime is reduced and the supply chain is optimized, and new thinking about the material, design, and manufacturing are enabled and 3D printing is used.

Among the most appropriate KETs for product design are those shown in Table 7.

Table 7. Implementation of KETs 4.0 in in product life cycle "Design".

\begin{tabular}{|c|c|c|c|c|c|}
\hline \multicolumn{2}{|c|}{ Product Component Level } & \multicolumn{3}{|c|}{ Product Structure Level } & Product System Level \\
\hline Raw material extraction & Design & Manufacturing & Logistic & Use & End of life \\
\hline \multicolumn{6}{|c|}{ KETs $(\mathrm{E}, \mathrm{E}, \mathrm{E}){ }^{*}$} \\
\hline \multicolumn{2}{|c|}{$\begin{array}{l}\text { - Digitalization } \\
\text { - Simulation } \\
\text { - Machine learning } \\
\text { - Big data } \\
\text { - Data mining } \\
\text { - Surrogate models } \\
\text { - Virtual and augmented reality } \\
\text { 3D printing }\end{array}$} & \multicolumn{3}{|c|}{$\begin{array}{l}\text { - Sensor and actuator } \\
\text { - CyberPhysical systems } \\
\text { - Ubiquous computation } \\
\text { - Virtual and augmented Reality } \\
\text { - Balanced scorecard } \\
\text { - Smart robotic } \\
\text { - Aditive manufacturing } \\
\text { - Collaborative robotic }\end{array}$} & $\begin{array}{l}\text { Cloud computing } \\
\text { - Fog } \\
\text { - Big data } \\
\text { - Online platforms } \\
\text { - Digital twin }\end{array}$ \\
\hline
\end{tabular}

This section shows the results of the tools, KPIs, standards, and KETs associated with the product design phase, for each of which both the element studied and a contribution are shown. An application of KET synergies and emerging knowledge contained in the techniques and tools of the unified framework of Figure 5, corresponds to the use of sustainable product data from STEP 10303. This data, when included in the industrial and social metabolism standards of a general and particular character, promotes the transfer to standards of knowledge of the science of measurement in the evaluation of the sustainable life cycle; the modelling of product and process information; and the interoperability of engineering applications. In general, the incorporation of KETs is of special interest when the surrogate model is incorporated for the modelling and optimization of sustainability through machine learning and deep learning [96,97].

\section{Conclusions}

Today the effects that our actions generate in the world are largely known. The CE arises on the assumption that our way of life damages the planet. Regarding the technical-economic aspects of the $\mathrm{CE}$, we conclude that not only do techniques and strategies based on the circularity of materials and products need to be incorporated, but procedures for managing resources and waste based on prevention and sustainability criteria also require inclusion in the framework. Furthermore, in our field of personal, professional, and community influence, the development of good practices intrinsic to the conception of the CE must be extended, such as reducing, recycling, rehabilitating, repairing, redistributing, restoring, redesigning, rethinking, remanufacturing, reusing, and recovering. This requires these postulates to be shared in a responsible, innovative, transversal, and solidarity way 
throughout the entire value or supply chain of the products and throughout the technical and biological cycle of the materials. Only in this way would the transition to a circular model be achieved which would ensure the continuity and regeneration of materials and products and life in all its dimensions, in addition to reversing the damage caused by the linear model.

In this work, the CE is identified as a paradigm for sustainability and is characterized based on its teleological, epistemological, ontological, axiological, and methodological aspects. It presents itself as a bioinspired paradigm on which to rely for the development of sustainable technical systems.

Various techniques, tools, standards, and indicators that contribute towards achieving the objectives and principles of CE in technical systems are identified and analysed. This analysis has been carried out on the three dimensions (pillars) of sustainability, with special attention paid to the environmental dimension, which is mainly linked to the contribution of the integration of technical systems in the natursphere, from the criteria of circularity, efficiency, and toxicity. These techniques and tools identified are oriented towards effects (to reduce impacts) or towards causes (to create value) for the purpose of their integration into the life cycle of the technical systems. As a result of this review, a three-dimensional matrix has been structured. This matrix contains three axes which relate natural and fundamental principles of the $\mathrm{CE}$, the dimension of eco-effectivity or creation of value $(\mathrm{C} 2 \mathrm{C})$, and the dimension of eco-efficiency or effects produced (LCA). These latter two harbour the three dimensions of the paradigm of the CE: The social, environmental, and economic dimensions.

Finally, a framework has been established in which life cycle technical systems are supported, both for the integration of $\mathrm{CE}$ techniques and tools oriented towards causes/effects, and for the consideration of the greater scope provided by the Industry 4.0 digital enablers, which allow the $\mathrm{CE}$ to be leveraged for the digital transformation towards sustainability. As our main contribution, a framework for the standardization of CE is proposed as a paradigm for sustainability. This framework has hitherto been absent from the bibliography, and allows the various regulatory aspects to be organized in a unified way for their consideration by the different standardization bodies. This framework of standardization of the CE includes four basic entities that apply specific tools, standards, KPIs, and KETs. The business entity represents the circular business that shows the most aggregated analysis unit of the circular value chain. Likewise, the product, process, and facility entities enable sustainability to be ensured in industrial and service operations. Furthermore, this framework is both multiscale and multilevel: Multiscale in that it can be implemented across different regions; and multilevel to the extent that it is applicable from business entity to product, process, and facility entities.

Author Contributions: Conceptualization, M.J.Á.-G., A.M.-G., and F.A.-G..; Investigation, M.J.Á.-G., A.M.-G., and A.C.-R.; Methodology, M.J.Á.-G. and F.A.-G.; Writing-original draft, M.J.Á.-G., A.M.-G., and A.C.-R.; Writing —review and editing, M.J.Á.-G., A.M.-G., and F.A.-G.

Funding: This research has received no external funding.

Conflicts of Interest: The authors declare no conflict of interest.

\section{References}

1. González de Molina, M.; Toledo, V.M. The Social Metabolism-A Socio-Ecological Theory of Historical Change; Springer: Berlin, Germany, 2014; Volume 3, ISBN 978-3-319-06357-7.

2. Esposito, M.; Tse, T.; Soufani, K. Introducing a circular economy: New Thinking with new managerial and policy implications. Calif. Manage. Rev. 2018, 60, 5-19. [CrossRef]

3. Kalmykova, Y.; Sadagopan, M.; Rosado, L. Circular economy-From review of theories and practices to development of implementation tools. Resour. Conserv. Recycl. 2018, 135, 190-201. [CrossRef]

4. Loiseau, E.; Saikku, L.; Antikainen, R.; Droste, N.; Hansjürgens, B.; Pitkänen, K.; Leskinen, P.; Kuikman, P.; Thomsen, M. Green economy and related concepts: An overview. J. Clean. Prod. 2016, 139, 361-371. [CrossRef]

5. Zinck, S.; Ayed, A.-C.; Niero, M.; Head, M.; Wellmer, F.-W.; Scholz, R.W.; Morel, S. Life cycle management approaches to support circular economy. In Designing Sustainable Technologies, Products and Policies; Springer International Publishing: Cham, Switzerland, 2018; pp. 3-9. 
6. Niero, M.; Rivera, X.C.S. The role of life cycle sustainability assessment in the implementation of circular economy principles in organizations. Procedia CIRP 2018, 69, 793-798. [CrossRef]

7. Jensen, J.P.; Prendeville, S.M.; Bocken, N.M.P.; Peck, D. Creating sustainable value through remanufacturing: Three industry cases. J. Clean. Prod. 2019, 218, 304-314. [CrossRef]

8. Ryen, E.G.; Gaustad, G.; Babbitt, C.W.; Babbitt, G. Ecological foraging models as inspiration for optimized recycling systems in the circular economy. Resour. Conserv. Recycl. 2018, 135, 48-57. [CrossRef]

9. McDonough, W.; Braungart, M.; Anastas, P.T.; Zimmerman, J.B. Applying the principles of green engineering to cradle-to-cradle design: Industry is using these tenets and principles to work toward sustainability. Environ. Sci. Tech. 2003, 37, 434A-441A. [CrossRef]

10. Gamage, A.; Hyde, R. A model based on Biomimicry to enhance ecologically sustainable design. Archit. Sci. Rev. 2012, 55, 224-235. [CrossRef]

11. Mi, Z.; Coffman, D.M. The sharing economy promotes sustainable societies. Nat. Commun. 2019, $10,1214$. [CrossRef]

12. Kirchherr, J.; Reike, D.; Hekkert, M. Conceptualizing the circular economy: An analysis of 114 definitions. Resour. Conserv. Recycl. 2017, 127, 221-232. [CrossRef]

13. Geissdoerfer, M.; Savaget, P.; Bocken, N.M.P.; Hultink, E.J. The circular economy-A new sustainability paradigm? J. Clean. Prod. 2017, 143, 757-768. [CrossRef]

14. Homrich, A.S.; Galvão, G.; Abadia, L.G.; Carvalho, M.M. The circular economy umbrella: Trends and gaps on integrating pathways. J. Clean. Prod. 2018, 175, 525-543. [CrossRef]

15. Kuhn, T.S. The Structure of Scientific Revolutions, 3rd ed.; University of Chicago Press: Chicago, IL, USA, 1962; ISBN 9781912281589.

16. Kivunja, C.; Kuyini, A.B. Understanding and applying research paradigms in educational contexts. Int. J. High. Educ. 2017, 6, 26. [CrossRef]

17. Bjørn, A.; Hauschild, M.Z. Cradle to cradle and LCA. In Life Cycle Assessment: Theory and Practice; Springer International Publishing: Cham, Switzerland, 2017; pp. 605-631. ISBN 9783319564753.

18. Halbe, J.; Adamowski, J.; Pahl-Wostl, C. The role of paradigms in engineering practice and education for sustainable development. J. Clean. Prod. 2015, 106, 272-282. [CrossRef]

19. Pauliuk, S.; Hertwich, E.G. Socioeconomic metabolism as paradigm for studying the biophysical basis of human societies. Ecol. Econ. 2015, 119, 83-93. [CrossRef]

20. Reich-Weiser, C.; Vijayaraghavan, A.; Dornfeld, D. Appropriate use of green manufacturing frameworks. In Proceedings of the 17th CIRP LCE Conference, Hefei, China, 19-21 May 2010; pp. 196-201.

21. Korhonen, J.; Nuur, C.; Feldmann, A.; Birkie, S.E. Circular economy as an essentially contested concept. J. Clean. Prod. 2018, 175, 544-552. [CrossRef]

22. Vanhamaki, S.; Medkova, K.; Malamakis, A.; Kontogianni, S.; Marisova, E.; Dellago, D.H.; Moussiopoulos, N. Bio-based circular economy in European national and regional strategies. Int. J. Sustain. Dev. Plan. 2019, 14, 31-43. [CrossRef]

23. Pauliuk, S. Critical appraisal of the circular economy standard BS 8001:2017 and a dashboard of quantitative system indicators for its implementation in organizations. Resour. Conserv. Recycl. 2018, 129, 81-92. [CrossRef]

24. Escrig-Tena, A.B.; Garcia-Juan, B.; Segarra-Ciprés, M. Drivers and internalisation of the EFQM excellence model. Int. J. Qual. Reliab. Manag. 2019, 36, 398-419. [CrossRef]

25. Pohle, A.; Blind, K.; Neustroev, D. The impact of international management standards on academic research. Sustain. 2018, 10, 4656. [CrossRef]

26. Veugelers, R.; Cincera, M.; Frietsch, R.; Rammer, C.; Schubert, T.; Pelle, A.; Renda, A.; Montalvo, C.; Leijten, J. The impact of Horizon 2020 on innovation in Europe. Intereconomics 2015, 50, 4-30. [CrossRef]

27. Mayer, P. Guidelines for Writing a Review Article; Zurich-Basel Plant Science Center: Zurich, Switzerland, 2009; Volume 82, pp. 443-446.

28. Squires, J.E.; Estabrooks, C.A.; Gustavsson, P.; Wallin, L. Individual determinants of research utilization by nurses: A systematic review update. Implement. Sci. 2011, 6, 1. [CrossRef] [PubMed]

29. Denzin, N.K.; Lincoln, Y.S. Handbook of Qualitative Research; SAGE Publications: Los Angeles, CA, USA, 2011; ISBN 978-1-4129-7417-2.

30. Pearce, D.W.; Turner, R. Economics of Natural Resources and the Environment; Johns Hopkins University Press: Baltimore, MD, USA, 1989. 
31. Ellen MacArthur Foundation. Growth Within: A Circular Economy Vision for a Competitive Europe; Ellen MacArthur Foundation: Cowes, UK, 2015.

32. Ellen MacArthur Foundation. Towards the Circular Economy; Ellen MacArthur Foundation: Cowes, UK, 2013; pp. 1-96.

33. Kobza, N.; Schuster, A. Building a responsible Europe-The value of circular economy. IFAC-PapersOnLine 2016, 49, 111-116. [CrossRef]

34. Oliveira Neto, G.C.D.; Pinto, L.F.R.; Amorim, M.P.C.; Giannetti, B.F.; Almeida, C.M.V.B. de A framework of actions for strong sustainability. J. Clean. Prod. 2018, 196, 1629-1643. [CrossRef]

35. Ghisellini, P.; Cialani, C.; Ulgiati, S. A review on circular economy: The expected transition to a balanced interplay of environmental and economic systems. J. Clean. Prod. 2016, 114, 11-32. [CrossRef]

36. Lieder, M.; Rashid, A. Towards circular economy implementation: A comprehensive review in context of manufacturing industry. J. Clean. Prod. 2016, 115, 36-51. [CrossRef]

37. Elia, V.; Gnoni, M.G.; Tornese, F. Measuring circular economy strategies through index methods: A critical analysis. J. Clean. Prod. 2017, 142, 2741-2751. [CrossRef]

38. Pomponi, F.; Moncaster, A. Circular economy for the built environment: A research framework. J. Clean. Prod. 2017, 143, 710-718. [CrossRef]

39. Tóth Szita, K. The application of life cycle assessment in circular economy. Hungarian Agric. Eng. 2017, 31, 5-9. [CrossRef]

40. Spangenberg, J.H.; Omann, I.; Hinterberger, F. Sustainable growth criteria: Minimum benchmarks and scenarios for employment and the environment. Ecol. Econ. 2002, 42, 429-443. [CrossRef]

41. Daozhong, C.; Qingli, Z.; Jie, W.; Xiaozhi, Z. Comparative analysis of ecological rucksack between open-pit and underground coal mine. Energy Procedia 2011, 5, 1116-1120. [CrossRef]

42. Suh, S.; Kagawa, S. Industrial ecology and input-output economics: An introduction. Econ. Syst. Res. 2005, 17, 349-364. [CrossRef]

43. Liwarska-Bizukojc, E.; Bizukojc, M.; Marcinkowski, A.; Doniec, A. The conceptual model of an eco-industrial park based upon ecological relationships. J. Clean. Prod. 2009, 17, 732-741. [CrossRef]

44. Jacobsen, N.B. Industrial symbiosis in Kalundborg, Denmark: A quantitative assessment of economic and environmental aspects. J. Ind. Ecol. 2008, 10, 239-255. [CrossRef]

45. Hannon, B. The structure of ecosystems. J. Theor. Biol. 1973, 41, 535-546. [CrossRef]

46. Murray, A.; Skene, K.; Haynes, K. The circular economy: An interdisciplinary exploration of the concept and application in a global context. J. Bus. Ethics 2017, 140, 369-380. [CrossRef]

47. Zhang, Y.; Li, Y.; Zheng, H. Ecological network analysis of energy metabolism in the Beijing-Tianjin-Hebei (Jing-Jin-Ji) urban agglomeration. Ecol. Modell. 2017, 351, 51-62. [CrossRef]

48. Rosen, M.A.; Dincer, I. Exergy as the confluence of energy, environment and sustainable development. Exergy 2001, 1, 3-13. [CrossRef]

49. Odum, H.T. Environmental Accounting. Emergy and Environmental Decision Making; John Wiley Sons: Hoboken, NJ, USA, 1996; p. 370.

50. Loiseau, E.; Junqua, G.; Roux, P.; Bellon-Maurel, V. Environmental assessment of a territory: An overview of existing tools and methods. J. Environ. Manag. 2012, 112, 213-225. [CrossRef]

51. De Pauw, I.; Kandachar, P.; Karana, E.; Peck, D.; Wever, R. Nature inspired design: Strategies towards sustainability. In Proceedings of the Knowledge Collaboration \& Learning for Sustainable Innovation ERSCP-EMSU Conference, Delft, The Netherlands, 25-28 October 2010; pp. 1-21.

52. Andersen, M.S. An introductory note on the environmental economics of the circular economy. Sustain. Sci. 2007, 2, 133-140. [CrossRef]

53. Norris, G.A. Integrating life cycle cost analysis and LCA. Int. J. Life Cycle Assess. 2001, 6, 118-120.

54. Vygotsky, L. Mind in Society: The Development of Higher Psychological Processes; Harvard University Press: Cambridge, MA, USA, 1980.

55. Weidema, B.P. The integration of economic and social aspects in life cycle impact assessment. Int. J. Life Cycle Assess. 2006, 11, 89-96. [CrossRef]

56. Boons, F.; Howard-Grenville, J.A. The Social Embeddedness of Industrial Ecology; Edward Elgar: Cheltenham, UK, 2009; ISBN 9781848449060.

57. Moya, I. Escenario de Estandarización en Economía Circular; UNE Normalización Española: Madrid, Spain, 2018. 
58. Pagoropoulos, A.; Pigosso, D.C.A.; McAloone, T.C. The emergent role of digital technologies in the circular economy: A Review. Procedia CIRP 2017, 64, 19-24. [CrossRef]

59. Dujin, A.; Geissler, C.; Horstkötter, D. Industry 4.0. The New Industrial Revolution. How Europe Will Succeed; Roland Berger: Munich, Germany, 2014; pp. 1-24.

60. Wang, L.; Törngren, M.; Onori, M. Current status and advancement of cyber-physical systems in manufacturing. J. Manuf. Syst. 2015, 37, 517-527. [CrossRef]

61. Uhlemann, T.H.-J.; Lehmann, C.; Steinhilper, R. The digital twin: Realizing the cyber-physical production system for industry 4.0. Procedia CIRP 2017, 61, 335-340. [CrossRef]

62. Gligoric, N.; Krco, S.; Hakola, L.; Vehmas, K.; De, S.; Moessner, K.; Jansson, K.; Polenz, I.; Van Kranenburg, R. Smarttags: IoT product passport for circular economy based on printed sensors and unique item-level identifiers. Sensors 2019, 19, 586. [CrossRef]

63. Liebel, G.; Marko, N.; Tichy, M.; Leitner, A.; Hansson, J. Model-based engineering in the embedded systems domain: An industrial survey on the state-of-practice. Softw. Syst. Model. 2018, 17, 91-113. [CrossRef]

64. Holmström, J.; Holweg, M.; Khajavi, S.H.; Partanen, J. The direct digital manufacturing (r)evolution: Definition of a research agenda. Oper. Manag. Res. 2016, 9, 1-10. [CrossRef]

65. Marina, L.A.; Trasnea, B.; Grigorescu, S.M. A multi-platform framework for artificial intelligence engines in automotive systems. In Proceedings of the 22nd International Conference on System Theory, Control and Computing, ICSTCC 2018, Sinaia, Romania, 10-12 October; pp. 559-564.

66. Posada, J.; Toro, C.; Barandiaran, I.; Oyarzun, D.; Stricker, D.; Amicis, R.; Pinto, E.; Eisert, P.; Döllner, J.; Vallarino, I. Visual computing as key enabling technology for industry 4.0 \& industrial internet. IEEE Comput. Graph. Appl. 2015, 35, 26-40.

67. Halenar, I.; Juhas, M.; Juhasova, B.; Borkin, D. Virtualization of production using digital twin technology. In Proceedings of the 20th International Carpathian Control Conference (ICCC), Kraków-Wieliczka, Poland, 26-29 May 2019; pp. 1-5.

68. Verhoef, P.C.; Stephen, A.T.; Kannan, P.K.; Luo, X.; Abhishek, V.; Andrews, M.; Bart, Y.; Datta, H.; Fong, N.; Hoffman, D.L.; et al. Consumer connectivity in a complex, technology-enabled, and mobile-oriented world with smart products. J. Interact. Mark. 2017, 40,1-8. [CrossRef]

69. Jiang, P.; Leng, J. The configuration of social manufacturing: A social intelligence way toward service-oriented manufacturing. In Proceedings of the International Conference on Innovative Design and Manufacturing ICIDM 2016, Auckland, New Zealand, 24-26 January 2016.

70. Tao, F.; Cheng, Y.; Zhang, L.; Nee, A.Y.C. Advanced manufacturing systems: Socialization characteristics and trends. J. Intell. Manuf. 2017, 28, 1079-1094. [CrossRef]

71. Zhu, K.; Kraemer, K.L. E-commerce metrics for net-enhanced organizations: Assessing the value of e-commerce to firm performance in the manufacturing sector. Inf. Syst. Res. 2002, 13, 275-295. [CrossRef]

72. He, M.; Devine, L.; Zhuang, J. Perspectives on cybersecurity information sharing among multiple stakeholders using a decision-theoretic approach. Risk Anal. 2018, 38, 215-225. [CrossRef] [PubMed]

73. Zhan, Z.H.; Liu, X.F.; Gong, Y.J.; Zhang, J.; Chung, H.S.H.; Li, Y. Cloud computing resource scheduling and a survey of its evolutionary approaches. ACM Comput. Surv. 2015, 47, 63. [CrossRef]

74. Laborie, F.; Røed, O.C.; Engdahl, G.; Camp, A. Extracting value from data using an industrial data platform to provide a foundational digital twin. In Proceedings of the Annual Offshore Technology Conference 2019, Houston, TX, USA, 6-9 May 2019.

75. De Marchi, V.; Di Maria, E. Sustainability Strategies, Investments in Industry 4.0 and Circular Economy Results; "Marco Fanno" Working Papers; Dipartimento di Scienze Economiche “Marco Fanno": Padova, Italy, 2019.

76. Cheutet, V.; Sekhari, A.; Corbeaux, N. PLM and BIM approach to support information management in nuclear decommissioning: A synthesis. In Proceedings of the IFIP Advances in Information and Communication Technology; Springer: Berlin, Germany, 2018; pp. 104-114.

77. Martín Gómez, A.M.; Aguayo González, F.; Marcos Bárcena, M. Smart eco-industrial parks: A circular economy implementation based on industrial metabolism. Resour. Conserv. Recycl. 2018, 135, 58-69. [CrossRef]

78. Fer, I.; Kelly, R.; Moorcroft, P.R.; Richardson, A.D.; Cowdery, E.M.; Dietze, M.C. Linking big models to big data: Efficient ecosystem model calibration through Bayesian model emulation. Biogeosciences 2018, 15, 5801-5830. [CrossRef] 
79. Loconto, A.; Barbier, M. Creating actionable knowledge for sustainability: A case of "Standards in the making". Res. Rural Sociol. Dev. 2017, 24, 115-133.

80. Sales, B.; Darmois, E.; Papadimitriou, D.; Bourse, D. A systematic approach for closing the research to standardization gap. In The Future Internet Assembly; Springer: Berlin/Heidelberg, Germany, 2012; pp. 18-29.

81. Mauser, W.; Klepper, G.; Rice, M.; Schmalzbauer, B.S.; Hackmann, H.; Leemans, R.; Moore, H. Transdisciplinary global change research: The co-creation of knowledge for sustainability. Curr. Opin. Environ. Sustain. 2013, 5, 420-431. [CrossRef]

82. Tecchio, P.; McAlister, C.; Mathieux, F.; Ardente, F. In search of standards to support circularity in product policies: A systematic approach. J. Clean. Prod. 2017, 168, 1533-1546. [CrossRef]

83. Folmer, E.; Berends, W.; Luttighuis, P.O.; Van Hillegersberg, J. Top is research on quality of transaction standards: A structured literature review to identify a research gap. In Proceedings of the 6th International Conference on Standardization and Innovation in Information Technology SIIT 2009, Tokyo, Japan, 8-10 September 2009; pp. 65-78.

84. Ding, A.Y.; Korhonen, J.; Savolainen, T.; Kojo, M.; Ott, J.; Tarkoma, S.; Crowcroft, J. Bridging the gap between internet standardization and networking research. Comput. Commun. Rev. 2013, 44, 56-62. [CrossRef]

85. Fomin, V.; Keil, T. Standardization: Bridging the gap between economic and social theory. In Proceedings of the International Conference on Information Systems, Brisbane, Australia, 10-13 December 2000; pp. 206-217.

86. Le May, A.; Mulhall, A.; Alexander, C. Bridging the research-Practice gap: Exploring the research cultures of practitioners and managers. J. Adv. Nurs. 1998, 28, 428-437. [CrossRef] [PubMed]

87. Lanfang, L.; Issam, S.; Chong, W.K.; Christopher, H. Integrating G2G, C2C and resource flow analysis into life cycle assessment framework: A case of construction steel's resource loop. Resour. Conserv. Recycl. 2015, 102, 143-152. [CrossRef]

88. Braungart, M.; McDonough, W.; Bollinger, A. Cradle-to-cradle design: Creating healthy emissions-A strategy for eco-effective product and system design. J. Clean. Prod. 2007, 15, 1337-1348. [CrossRef]

89. Reijnders, L. Are emissions or wastes consisting of biological nutrients good or healthy? J. Clean. Prod. 2008, 16, 1138-1141. [CrossRef]

90. McDonough, W.; Braungart, M.; Anastas, P.T.; Zimmerman, J.B. Applying the principles of green engineering to Cradle-To-Cradle design. Environ. Sci. Technol. 2003, 37, 434A-441A. [CrossRef]

91. Bach, V.; Minkov, N.; Finkbeiner, M. Assessing the ability of the Cradle to Cradle Certified ${ }^{\mathrm{TM}}$ Products Program to reliably determine the environmental performance of products. Sustainability 2018, 10, 1562. [CrossRef]

92. Niero, M.; Hauschild, M.Z. Closing the loop for packaging: Finding a framework to operationalize circular economy strategies. Procedia CIRP 2017, 61, 685-690. [CrossRef]

93. Scheepens, A.E.; Vogtländer, J.G.; Brezet, J.C. Two life cycle assessment (LCA) based methods to analyse and design complex (regional) circular economy systems. Case: Making water tourism more sustainable. J. Clean. Prod. 2016, 114, 257-268. [CrossRef]

94. Despeisse, M.; Ball, P.D.; Evans, S.; Levers, A. Industrial ecology at factory level—A conceptual model. J. Clean. Prod. 2012, 31, 30-39. [CrossRef]

95. Huang, A. A Framework and Metrics for Sustainable Manufacturing Performance Evaluation at the Production Line, Plant and Enterprise Levels. Ph.D. Thesis, University of Kentucky, Lexington, KY, USA, July 2017.

96. Nosratabadi, S.; Mosavi, A.; Keivani, R.; Aram, F. State of the art survey of deep learning and machine learning models for smart cities and urban sustainability. Preprints 2019. [CrossRef]

97. Bertoni, A.; Dasari, S.K.; Hallstedt, S.I.; Petter, A. Model-based decision support for value and sustainability assessment: Applying machine learning in aerospace product development. In Proceedings of the 15th International Design Conference, Dubrovnik, Croatia, 21-24 May 2018; pp. 2585-2596.

(C) 2019 by the authors. Licensee MDPI, Basel, Switzerland. This article is an open access article distributed under the terms and conditions of the Creative Commons Attribution (CC BY) license (http://creativecommons.org/licenses/by/4.0/). 